\title{
THE FISHES OF SAN DIEGO, CALIFORNIA.
}

\author{
BY \\ Carl H. Eigenmann, \\ Professor of Zoology, Indiana University.
}

(With Plates $\mathrm{x}-\mathrm{x}$ VIII).

The present paper contains an account of the observations made by me on the fishes of San Diego and vicinity from December 11, 1888, to March 4, 1890.

Especial attention was paid to the spawning habits and seasons, the embryology, and migration of the fishes of southern California. A diary was kept of the occurrence of each species throughout the year 1889 and part of 1890 .

My knowledge of the occurrence of each species is largely based on observations of the fish brought into the markets, which I visited twice or thrice daily, and of those caught with hook and line by the numerous habitual fishermen found on each of the wharves, and of those caught by the seiners whom I accompanied on several occasions. During the early part of 1888 each individual fisherman sold his catch as best he could and the data for this part of the year are not as full as for the latter part of 1888 , when practically the whole catch was brought to two markets, where I could see the fish as they were unloaded. The knowledge of the ocean fishes is largely derived from frequent visits to ocean tide-pools, from the fish brought to the markets, and from a twoweeks' stay on the Cortes Banks. As a matter of course, hundreds of specimens of most species have been observed to every one preserved, and the present paper is to be looked upon as a contribution to the economic history of the fishes, rather than to the anatomy of the various species.

With two exceptions the types of the new species discovered and otherwise interesting specimens have been deposited in the U.S. National Museum. A nearly complete series of types has been placed in the British Museum and minor series in the Museum of Comparative Zoology and the California Academy of Sciences.

The fishing grounds about San Diego are: (1) San Diego Bay; (2) False Bay; (3) the shoal water (down to 100 fathoms) skirting the coast; (4) the Coronado Islands; and (5) the Cortes Banks. There are shallows off Coronado Beach which have not been examined. 
The faunæ of Nos. 1 and 2 are essentially alike and quite different from those of 3 to 5 . The former are characterized by the presence of Scicenida, Embiotocida, Atherinida; the latter, by the Scorpanida, Sphyrcenida, Scombrida, etc.

San Diego Bay is about 18 miles long by 1 to several miles wide. Its shores are sandy or muddy. There being no streams emptying into it it contains pure sea water. False Bay is much smaller and shallower and in winter receives the water of the San Diego River.

Only two methods of taking fish are employed in these two bays, viz, by seine and by gill net. The latter is only occasionally used, but so effective is the seining that unless it is stopped (all of it is illegal) the fisheries of the bay will soon be worth nothing.

Only two methods of fishing are employed off shore, trolling and hand-line fishing. The trawl and gill nets are not used. The trolling is employed to catch Spanish mackerel and barracuda, the hand line to eatch white-fish and rock-cod. The gill net and troll could probably be successfully used in the shoal water off Coronada Beach.

The young of many of the species the adult of which are always found outside often enter the bay. For instance, tinkers abound in the bay, while adult mackerel are never found, except outside. Young barracuda are sometimes found in abundance, half-grown Spanish mackerel enter the bay, and the young Paralebrax clathratus are common while the adult is usually taken outside.

Those specimens of outside species living in deeper water are always larger than those coming from shallower water.

On the Cortes Banks the young of the species of the genus Sebastodes abound on the elevated ridge, while the adult are always found in deeper water.

Those representatives of species abundant farther north are frequently much larger than the average size of the northern individuals. For instance, Sebastodes proriger reaches on an average 10 inches near San Francisco, while one found here measured about 24 inches. This may be partly explained by the fact that these specimens usually come from deep water.

The color of the same species of bottom fishes inhabiting the bay and the outside varies greatly, and even the same species at different depths or on different bottom, show remarkable changes.

Sebastodes vexillaris varies from flesh color to the brightest scarlet and olive color. A local fisherman explains the color of this fish by the fact that fishes in shallow water are likely to be blacker, those in deep water lighter, and those on hard, rocky bottom of moderate depth bright red. Scorpana guttata deserves special mention. It is found both in the bay and outside, on the rock-cod banks. Those found in the bay are dull colored, chiefly brown, variously mottled, while those from the outside have the brown replaced by the brightest scarlet. The color is so strikingly different that I have repeatedly thought the two fishes to be distinct. 
Four lists of the fishes of San Diego have been published. Jordan and Gilbert in their first list, referred to as J. and G., 'S0 (Proc. U. S. Nat. Mus., 1880, 23) gave notes on fifty-seven species collected by them. Rosa Smith, in her first list, referred to as R. Smith, '80 (Nov., 1880), enumerated eighty-two species. In their second list Jordan and Gilbert, '80a (l. c. 452) enumerated eighty three. The fourth, or Rosa Smith's second list, '85 (West American Scientist, June, July, and August, 1885), contained the names of one hundred and nine species.

In the Proceedings of the U. S. National Museum for 1881, Jordan and Gilbert give notes on the fishes of the Pacific Coast in general. This paper is quoted as J. and G.,' 81 ; their synopsis of the fishes of North America as J. and G.,'82. Our three papers, Notes from the San Diego Biological Laboratory, I, II, and III, are referred to as '89, '89a, and '90. The other papers are quoted in full.

The present list enumerates one hundred and seventy species and varieties. Of these I have observed all but the following during my stay at San Diego. (1) Carcharinus lamiella; (2) Manta birostris; (3) Hippocampus ingens; (4) Siphostoma punctipinne; (5) S. Californiense; (6) Gasterosteus microcephalus; (7) Caranx caballus; (8) Chcetodipterus faber; (9) Neoclinus blanchardi; (10) Spharoides politus; (11) Diodon hystrix. I am not certain whether numbers $3,7,8,10$, and 11 of the foregoing should not be discarded. They have not been taken here within the last ten years. The others have been taken either by Rosa Smith prior to 1887 or they have been authoritatively recorded from here by others. The species (60) added to the San Diego fauna during the period covered by this paper have already been enumerated: in the Proceedings of the U. S. National Museum, 1888, 463: the West American Scientist for October and November, 1889: the Proceedings of the California Academy of Sciences, second series., vol. III, p. 1, 1890, and in the American Naturalist February, June, and December, 1891, and January'92. Of the sixty species added over twenty were new to science, most of the others being forms already well known from the northern part of California. Comparatively few southern species have been added.

I have found surprisingly few species of pelagic fish eggs. This is probably due to the limited means of collecting them and to the fact that at least 30 per cent of the teleosts inhabiting the region are viviparous.

The following synoptical key will perhaps assist future investigators to identify some of the species of fish eggs found at San Diego.

$$
\text { A key to the species of ova observed. }
$$

* The egg is large and has a leathery covering; the young leaves it in an advanced stage possessing most of the characters of the adult............ Selachians. $t$

A. Egg case flat, purse shaped ............................. ScYLLIORHINUS.

$A A$. Egg case spirally twisted, subconical.................... Heterodontus.

† Only two of the many genera of Selachians found here are oviparous. 
* * The egg is small, with a zona radiata for covering; the young leaves it as a larva.

a. The egg is hatched in the mother.

b. All the intraovarian food is supplied by the large yolk, which always contains one or more oil-globules. Young leaving mother in larval stages.... SEBASTODEs.

$b b$. Intraovarian food mostly supplied by secretions of the ovary. Eggs small, owing to the nonformation of food deutoplasm. Development characterized by the hypertrophy of the hind gut and later by the hypertrophy of the fins and their capillaries. Young leaving mother in a mature stage. ....... ЕмвIотосIDE.

aa. The egg is hatched in water.

c. Nonpelagic eggs.

d. Eggs very large, 5 millimeters or more in diameter........ PoRichthys. $\ddagger$ dd. Eggs much less than 5 millimeters in diameter.

$e$. Zona radiata without filaments or projections.

f. Eggs cohesive (pelagic?); several oil globules.. OligocotTus analis.

$f f$. Eggs adhesive, protoplasm yellow, no oil globules.

(Leptocottus.?)

Clupea mirabilis.

$e e$. Zona radiata with filaments scattered over its whole surface.

$g$. Filaments numerous, placed directly on the zona.

Fundulus Parvipinnis.

gg. Filaments few, very long, tapering, set in sheaths of the zona.

h. Eggs large 2.4 millimeters in diameter, amber colored.

(GOBIESOCIDÆ.)

Tylosurus Exilis. $\oint$ ggg. Filaments few, their disk-like basal expansions hollow, fitting into projections of the zona.

(ATHERINID A.)

i. About ten filaments; several oil-globules during the early stages................ AtHerinopsis.

$e e$. Zona radiata with filaments or other processes on restricted regions.

$j$. Mushroom-shaped processes near micropyle.

Gasterosteus.

jj. A meshwork of filaments attached in a circle about the micropyle. The zona much elongate, clubshaped, attached to lower surface of rocks.

ZipHLOGOBIUS CALIFORNIENSIS.

ijj. Numerous fine filaments forming a cushion over nearly half the zona; yolk salmon pink; white and deep purple oil-globules.

Isesthes.

$k$. Spawning in March in rocky tide pools of the ocean beach.

I. GILBERTI.

$k k$. Spawning in May in the bay.

I. GENTILIS.

‡ We have not seen the developing eggs of this species. They are probably fastened to objects in some way or other. The male is provided with a large (nidamental?) gland.

ff The eggs of the other members of this family occurring here have not been examined. 
cc. Pelagic eggs.

l. A large number of ova embedded in a transparent matrix;

11. Ova separate.

Fierasfer.

$m$. No oil globule.

$n$. Yolk in large segments, clear.

o. Round ova.......... Stolephorus COMPRESSUS oo. Oval ova.. STOLEPHORUS DELICATISSIMUS AND

$\mathrm{mm}$. One or more oil globules.

RINGENS.

p. Embryo developing black pigment in the ovum.

$q$. Oil globule at the time of hatching situated at the anterior end of the yolk.

Paralabrax nebulifer.

$p p$. Embryo developing black and brownish pigment in the ovum.

$r$. Oil globule at the time of hatching situated at the anterior end of the yolk.

s. Yellowish pigment at the time of hatching in definite regions, viz:-at the mouth, at the middle of the body, over the anus and at some distance behind the anus... Paralabrax maculofasciatus.

$r r$. Oil globule at the time of hatching at or near the posterior end of the yolk.

$t$. Chromatophores appearing when gastrula covers about one-third of the yolk, proliferated from the embryonic shield and the entire embryonic ring; fewer chromatophores on the tail at the time of hatching... SCIAENA SATURNA (and other species of Sciaenidae?)

tt. Chromatophores appearing when the gastrula covers about two-thirds of the yolk, proliferated from the embryo only; more chromatophores on tail at the time of hatching.. HYPSOPSETTA GUTTULATA.

aaa. The eggs are hatched in a brood-pouch along the ventral surface of the

\section{UNIDENTIFIED EGGS.}

Species No. 1. Plate x, figs. 6-9.

One egg of this species was dredged August 14, at 9:15 a. m., in the stage represented by fig. $6, \mathrm{Pl}$. I. The egg is transparent, the globule amber-colored. The egg measures 0.80 millimeter, the oil globule 0.12 millimeter. The pigment cells were minute and the difference between yellow and black not well marked.

Four hours later the tail is just beginning to develop. The oil globule is very sparingly pigmented; the yolk sack in the neighborhood of the globule is covered with many yellow and one or two black cells. The color cells on the embryo are very small and numerous, the black ones as usual are on the dorsal, the yellow ones on the ventral surface of the embryo. 
Another egg was found August 28, and is represented in fig. 8. The tail is much developed and the pigment more conspicuous.

On hatching the yolk sack is 0.80 millimeter long, and the total length of the larva (fig. 9) is $\mathbf{1 . 4}$ millimeters. The globule is well pigmented and there are a number of chromatophores on the yolk sack below, in front of the globule. The chromatophores are pretty evenly distributed over the fish.

\section{Species No. 2. Pleuronichthys cœnosus? Plate x, figs. 10-13.}

A single egg of this species was found April 26, at 12:30 p. m. The marginal infolding of the gastrula was well begun.

The egg was smaller than that of Hypsopsetta and was supposed to be that of Pleuronichthys cœnosus. It measured 0.71 millimeter in diameter and the single small globule was scarcely more than 0.08 millimeter in diameter.

The blastopore closed somewhat over seven hours after the stage represented in fig. 10. Nineteen hours after fig. 10 pigment has been formed, the embryo is comparatively narrow. In place of Kupffer's vesicle there was a double vesicle, one behind the other, as represented in figs. 11 and 12. This was in all probability a pathological specimen.

In the figures only black-pigment cells are drawn; in later stages numerous greenish-yellow cells become prominent wherever there are black ones. They are especially abundant about the head and on the body near the end of the yolk sack.

\section{SUMMARY OF THE DAILY OBSERVATIONS.}

The following lists are an abridgment of the detailed records kept for the species.

The following abbreviations have been used :

b. Found in San Diego Bay.

$q$ or $\delta$. Ripe female or male, or female with young if a viviparous species.

e. Eggs were procured (usually by skimming).

y. Young were taken.

a. Abundant.

f. Few.

c. Common.

Numbers ordinarily indicate the date of the month when specimens were seen. Thus, after No. 11, August 20, 28, indicates that specimens were taken on August 20 and 28. If a number is followed by an* it indicates the number of specimens taken. Thus, under No. 59, October $31,1^{*}$ indicates that one specimen was taken on October 31 , etc. 


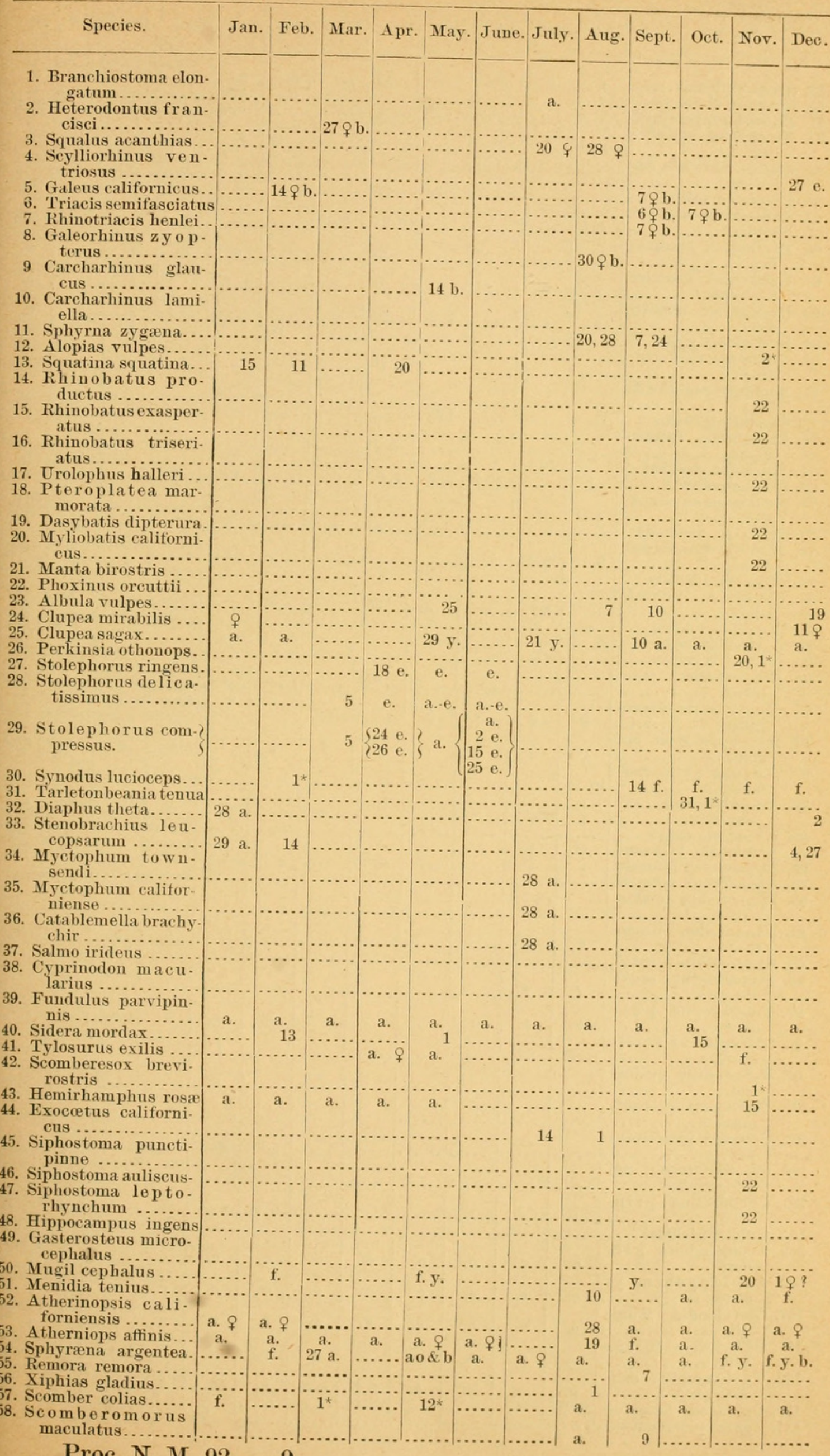

Proc. N. M. 92 $-9$ 


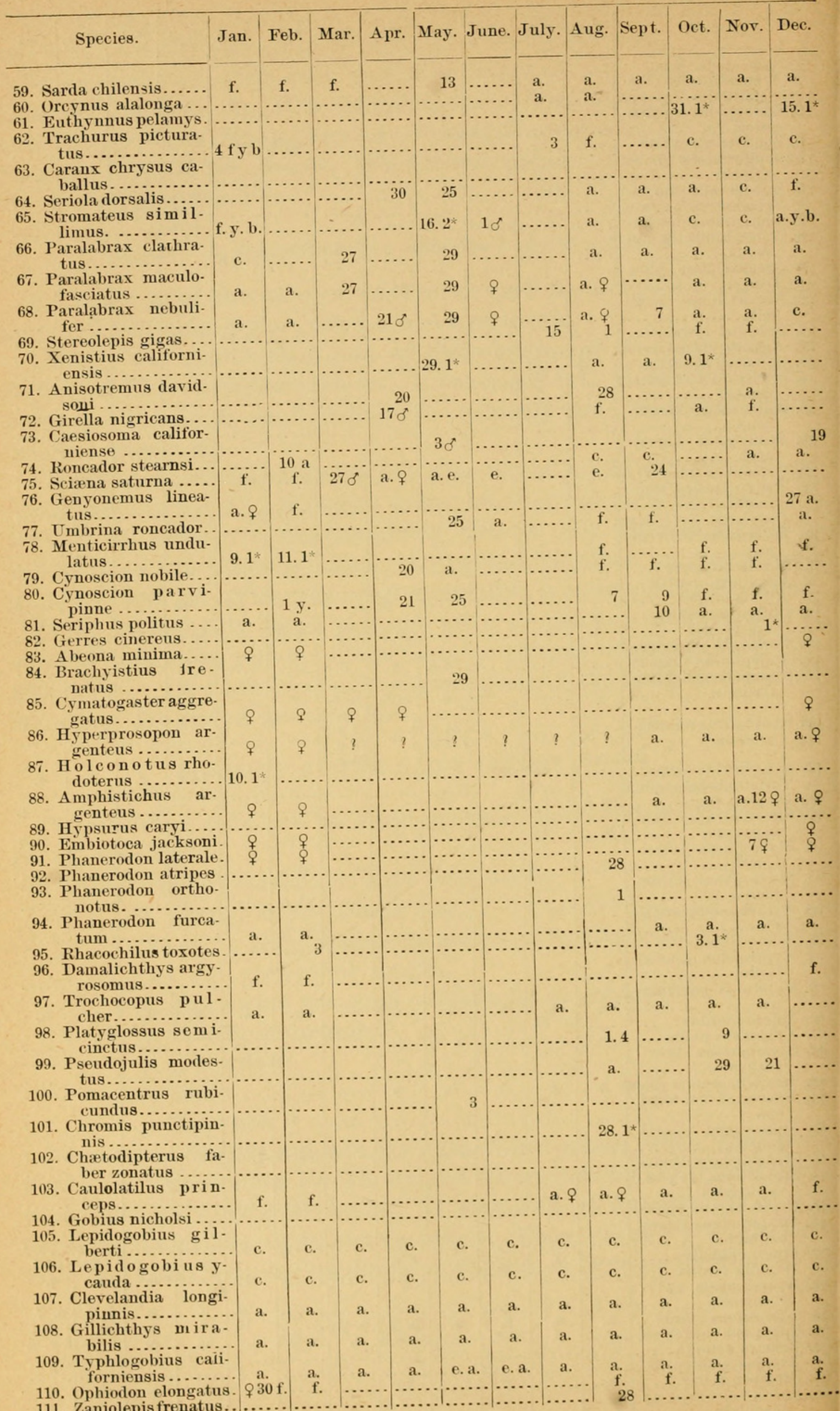




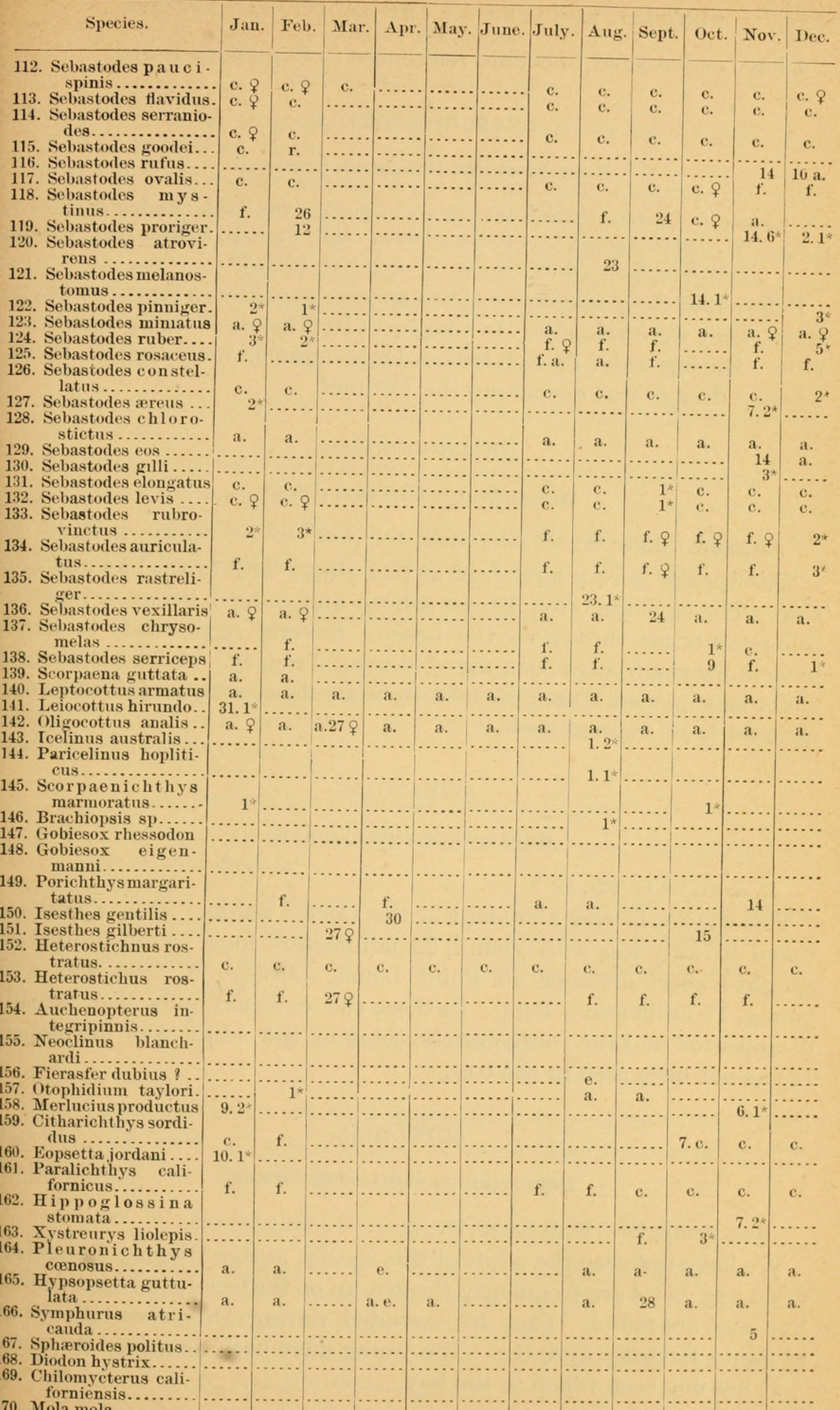


GENERAL REMARKS ON THE INDIVIDUAL SPECIES.

I have endeavored to collate references to San Diego fishes.

\section{BRANCHIOSTOMIDÆ.}

Branchiostoma elongatum Sundevall.

Cooper, in Cronise, Natural Wealth of California. 498, 1868. Jordan \& Gilbert, '81. 29 (not seen). As B. lanceolatum. Gill, Proc. U. S. Nat. Mus., v. 1882, 515; Rosa Smith, July, '85, 55. E. Am. Nat. 1892, 70.

Before 1891 three specimens of this species were known from San Diego Bay. They were taken by Dr. Cooper in 10 fathoms of water near Roseville. During July, 1891, I took a large number near Ballast Point, where a dredge was deepening the channel.

\section{HETERODONTID $Æ$.}

\section{Heterodontus francisci (Girard).}

Jordan \& Gilbert, '80, 34; Rosa Smith, July, '80a., 458., id., '82, 30. R. Smith, '85.

This species is very abundant at San Diego both in the bay and outside. The eggs are often driven ashore and lodged between rocks in tide pools or are thrown on the beach. Several eggs ready to hatch have in previous years been found during January. A female about 1 meter long opened March 27, 1889, by some fishermen, contained an egg inclosed in its twisted shell.

\section{SPINACID Æ.}

Squalus acanthias Linnæus.

E. \& E., '89,1; '89a, 12.

This species is very abundant at the Cortes Banks. One specimen, taken in July was with young, 22 millimeters long. One individual caught a short distance off Point Loma, January 9, 1890, was with young, 11 millimeters long. In these the external gills had already disappeared and the characteristic color of the adult was developed. It has not been seen in the bay.

\section{SCYLLID A.}

\section{Scylliorhinus ventriosus Garman.}

Rosa Smith, '85. E. \& E., '89, 13.

We have not seen the adult of this species at San Diego. The empty dried egg cases are frequently thrown up on the beach and occasionally live ones are found. They are extruded during December (February at Santa Barbara, J. \& G.). The young have been described by us $l$. c.

It has not been taken in the bay. 


\section{GALEORHINID $A$.}

\section{Galeus californicus (Gill).}

J. \& G. '80, 34, as Mustelus californicus; R. Smith,'80, Mustelus hinnulus.

J. \& G. '80a, 458; id. '81a, 31. R. Smith, July, '85.

This species is quite common in San Diego Bay. A specimen eaught with hook and line, February 14, 1890, was with young. There were fourteen and the yolk was all or nearly all absorbed. The specimen was mutilated and the young had been taken from it when it was examined. They were evidently nearly ready to be freed.

\section{Triacis semifasciatus Girard.}

J. \& G. '80, 34; R. Smith, '80; J. \& G. '80a, 458; id. '81, 31; R. Smith, '85, July. E. \& E. ' $89 \mathrm{a}, 13$.

The females of this species are abundant in the bay during sum. mer and are frequently taken with hook and line. A few are also found in wirter. Embryos in advanced stages were taken from the mother in September and October. The young have been described $l$. $c$.

\section{Rhinotriacis henlei Gill.}

E. \& E., '89a, 13.

A single specimen of this species was taken with hook and line September 7, 1889. It contained but three embryos in either uterus, each 115 millimeters long.

\section{Galeorhinus zyopterus Jordan \& Gilbert.}

R. Smith '80, as G. galeus; J. \& G. '80a, 458; id.' '81, 32; id. '82, 871; R. Smith '85, July; E. \& E. '89a, 13.

Common in the bay in summer or during the early part of gestation. Two femâles taken August 30, 1890, had young 50 millimeters and 80 millimeters long respectively. One specimen was taken off Point Loma, February 14, 1890.

\section{Carcharhinus glaucus (L.).}

E. \& E. ' $89,1$.

Three large specimens, nearly 3 meters long, were taken in San Diego Bay May 14, 1889. It was found to be quite abundant on the Cortes Banks during July and August.

Carcharhinus lamiella Jordan \& Gilbert.

R. Smith '80; J. \& G. '80a, 458. J. \& G. '81, 32 all as Eulamia lamia. J. \& G. Proc. U. S. Nat. Mus. v. 110, 1882, as Carcharias lamiella; id.' '82, 60 as Eulamia lamia, and 873 as C. lamiella. R. Smith, '85, July.

Only two specimeus of this shark have been taken as yet. They were procured by Jordan \& Gilbert in 1880. 


\section{SPHYRNIDA.}

Sphyrna zygæna (L.).

E. \& E. ' $89 \mathrm{a}, 10$ and 11.

This species is not uncommonduring summer. A large specimen was taken on the Cortes Banks in August. One was caught in the bay on September 6 and others were taken off Point Loma August 28 and September 24. It seems to be always accompanied by Echeneis remora.

\section{ALOPID E.}

Alopias vulpes (Gmelin).

Two specimens of this species were taken in the fall of 1890 .

\section{SQUATINIDE.}

\section{Squatina squatina (L.).}

R. Smith '80; J. \& G. '80a, 458; id. '81, 33; R. Smith '85, July.

This species is probably found in the bay throughout the year. It is not infrequently caught off the wharves. Specimens were seen on April 20, 1889, and January 15 and February 11, 1890.

\section{RHINOBATIDA.}

Rhinobatus productus Ayres.

J. \& G. '80, 34; R. Smith '80; J. \& G. '80a, 458; id. '81, 34; id. '82, 876; R. Smith '85, July.

Caught off the wharves in spring.

Rhinobatus exasperatus Jordan \& Gilbert.

J. \& G. ' 80,32 ; R. Smith ' 80 ; J. \& G. '80a, 458; id. ' 81 ; id. ' 83,63 and 876 ; R. Smith' '85, July.

Common in the bay.

Rhinobatus triseriatus Jordan \& Gilbert.

R. Smith, '80; J. \& G., '80a, 458; id., '81, 34; id., '82, 64; R. Smith, '85, July. Not uncommon in the bay.

\section{DASYBATIDA.}

\section{Urolophus halleri Cooper.}

J. \& G., '80, 31; R. Smith, '80; J. \& G.,'80a, 457; id., '81, 35; id., '82, 46; R. Smith, '85, July.

Very common.

Pteroplatea marmorata Cooper.

J. \& G., '80, 31; R. Smith, '80; J. \& G., '80a, 457; id., '81, 35; id., '82, 47; R. Smith, '85, July.

Common. 
Dasybatis dipterura Jordan \& Gilbert.

J. \& G., '80, 31; R. Smith, '80; J. \& G., '80a, 457; id., '81, 35; id., '83, 48; R. Smith, '85, July.

One specimen taken with hook and line in October, 1889; another in a seine November, 1890.

$$
\text { MYLIOBATIDA. }
$$

\section{Mybliobatis californicus Gill.}

J. \& G., '80, 31; R. Smith, '80.

Common.

MANTID E.

Manta birostris (Walbaum).

No authentic specimens have been recorded from here.

Jordan \& Gilbert eredit it to San Diego on the authority of whalers. Mr. Medina elaims to have seen one about five years ago. None of the other fishermen know anything about it.

\section{CYPRINID $Æ$.}

Phoxinus orcuttii Eigenmann \& Eigenmann.

E. \& E., $90,2$.

This species is very abundant in the Temecula River, at the Temecula station, and in its tributaries. Some specimens were also found at San Bernardino.

\section{ALBULID $A$.}

\section{Albula vulpes (Linnæus).}

J. \& G., '80, 30; R. Smith, '80; J. \& G., '80a, 457; id., '81, 37; id., '82, 258; R. Smith,'85, July.

This species has not, at any time during the past year, been abundant at San Diego. It is occasionally caught during the summer and early spring. A few specimens were taken September 10 and it was not seen again till December 19, when a single small individual was taken. I have not seen it with ripe sexual elements.

\section{CLUPEID $\mathrm{E}$.}

\section{Clupea mirabilis Girard. (Plate XI.)}

J. \& G., '80, 30; R. Smith, '80; J. \& G., '80a, 457; id., '81, 37; id., '82, 265; R. Smith, '85, July. Eigenmann, Am. Nat., 1, Mareh, 1889.

This species entered San Diego Bay September 11, 1889, and no more were seen after February 15, 1890. It spawns probably during the whole time of its stay here, as ripe females were seen the first and last days it was taken. The young have not been observed in the bay during summer. The whole of the catch is sold fresh.

On January 3, 1888, a ripe male and a ripe female were procured, and although the fish had been dead some time fertilization was success- 
fully attempted. The eggs are very adhesive, and come from the ovary * in long strings. Shortly after they have been deposited they lose their adhesive power, and if they are then freed from the objects to which they have become attached they do not adhere again.

The membrane at the time of deposition is greatly shriveled and does not become distended till some time afterwards.

The yolk is collected in small spheres; it is grayish while the proto plasm is yellow and collects at the side of the egg. This fact enables one to trace the formation of the germinal disk quite readily. In an hour the protoplasm is well collected at the ectodermal pole, while processes extend from it over the yolk and others probably in between the yolk spheres. Frequently there is also a slight thickening of protoplasm over the entodermal pole. The fate of this has not been determined. Fig. 4.

One hour and fifty minutes after fertilization one of the eggs began to segment. The segmentation furrow descends slowly, producing slight folds on the surface of the blastomeres on either side of the furrow. With the descent of the furrow the blastomeres become more and more separated. When the furrow has reached the base of the germinal disk it slowly closes up again, the blastomeres becoming closely appressed. At one hour and fifteen minutes from the beginning of the first segmentation the second furrow appears. At one hour and fortyfive minutes the third cleavage has been completed in several eggs. (Fig. 15.) It is now seen that the segmentation is not quite symmetrical, and the third cleavage, which invariably leaves eight cells in pelagic eggs in this case, produces five or six or seven as well as eight, and these are not very regularly arranged. This fact is undoubtedly due to the hastening of the segmentation in some cells and the retardation in others.

The development of this species does not differ greatly from that of the shad, and the accompanying figures probably sufficiently illustrate the different stages.

The meridian of the embryo comes to lie in a horizontal plane.

Two days after fertilization the embryo begins to move and the heart beats.

Six days and a half after fertilization one of the membranes was empty, but the fish could not be found. The remaining embryos remained active in the shells five days longer when all of them died.

The larvæ or young of this species I have never found.

\section{Clupea sagax Jenyns.}

J. \& G., '80, 30; R. Smith, '80; J. \& G., '80a, 457; id., '81, 37; id., '82, 265 ; R. Smith, '85, July.

This species enters San Diego Bay about the first of September (large ones were first seen the past season on September 10) and remains till some time in March. Large schools of them are found about the wharves. Few are caught in seines, and many of these are 
not utilized. Some are eaught with grab hooks off the wharves, and are sold at 5 cents per dozen. They reach a length of $0.30 \mathrm{~m}$.; but few specimens of such size are caught. At times they are in such abundance that bushels of them are left at low tide in the small puddles about piles.

Young ones remain in the bay during the summer.

The spawning season has not been ascertained.

\section{Perkinsia * othonops R. S. Eigenmann.}

American Naturalist, February, 1891.

One specimen was obtained with hook and line among mackerel in November, 1890.

\section{STOLEPHORIDÆ.}

The members of this family are probably found here throughout the year, but they are certainly much more abundant in spring and summer than in winter (if they are here in winter at all). During spring and summer they furnish a large per cent of the food of all the larger fishes. The species inhabiting San Diego waters may be distinguished by the following key:

a. Spindle-shaped, form of Clupea sagax, no silvery lateral band, bluish above, not translucent. A. 22; Head $3 \frac{1}{2}$. Ova oval. Young more compressed, sides silvery but without well-defined band, not translucent................... ringens. aa. Strongly compressed, a silvery lateral band, translucent in life. Head $4 \frac{1}{2}$.

b. A. 23 ; depth $4 \frac{8}{4}$. Ova oval............................ delicatissimus. bb. A. 31 ; depth $3 \frac{a}{4}$. Ova round......................................

The pelagic eggs of these species are the most striking feature of the surface fauna in April, May, and June. The oval eggs were first obtained on April 18, and on account of their bizarre appearance were at first set aside as not fish eggs, but the gastrulation soon convinced me that they were. They are so abundant during May that quantities have been obtained simply by several times throwing the skimming net over the water and drawing it in while standing on the float of a boathouse. The oval eggs of delicatissimus, ringens were the first to appear, the round eggs of compressus appear later. The yolk is collected in clear transparent spheres.

\section{Stolephorus ringens (Jenyns). (Plate XII).}

Girard, Pacific R. R. Survey x. 334, 1859 (as Engraulis mordax) J. and G., '80, 30 ; R. Smith ' 80 ; J. and G. ' $80 a$ 457; id. ' 81 , 36; id. ' 82 , 272. R. Smith '85, July; E. and E. Contrib. San Diego Biol., Lab. I, West Am. Scient., June, '89.

This is the largest anchovy found at San Diego. It is found in the bay in summer and ranges from the surface to a depth of about 100 fathoms in the ocean off Point Loma. It is found in the stomachs of

* This genus is dedieated to the Hon. George C. Perkins, of San Francisco, ex-governor of California, who has for many years materially aided scientific research in the State of California. 
pelagic species like the albicore and in that of the bottom fishes like the species of Sebastodes.

Specimens of this species are even more numerous in the summer in the bay than Clupea sagax in winter. They swim in large schools and frequently when frightened by large fishes below them or for other reasons the heads of a whole school of them will be thrust out of water. The pelicans at this time dive in among them and eatch large numbers. Sehools of Tylosurus exilis flank them and by sudden darts eateh many. They are thus beset on all sides by enemies. They feed on crustacea and larval fishes.

I have not definitely decided which of the oval eggs belong to this species and which to delicatissmus.

\section{Stolephorus delicatissimus (Girard). (Plate XII.)}

Girard, Proc. Acad. Nat. Sci. Philad. vir, 1854, 154 and Pacific R. R. Survoy x, 325,1859 ; J. and G. ' 80,30 ; R. Smith ' 80 , J. and G. '80a, 457; id. '81, 38; id. '82, 276; R. Smith, '85, July; E. and E. Contrib. San Diego Biol. Lab., I, West Am. Scient., June, 1889.

This species is very abundant in San Diego Bay. I have not determined whether it remains throughout the year or not. It certainly is very common during summer or from March to September. Jordan and Gilbert have found it abundant here in January.

Development of Stolephorus Delicatissimus and Ringens.

(Plate XII.)

The eggs of these two species differ from most other pelagic eggs in their elongate shape. The eggs are transparent. The yolk is totally segmented. The eggs vary greatly in size and shape, and at first I supposed them to be three distinct species. The measurements are 0.81 by 0.57 millimeters, 0.89 by 0.49 , and 0.70 by 0.50 . Oval eggs which may be referred to this genus have been described by M. Kowalewski,* Wenckebach, $\dagger$ and Raffaele $\ddagger$ (who correctly identifies them). Agassiz $\&$ Whitman $\S$ have described a species of Stolephorus as an Osmerus.

The eggs of Osmerus are provided with a peculiar double zona, the outer layer of which is reflexed at the time of spawning, and remains attached to the inner part around the micropyle.

These are the most abundant of the pelagic eggs found at San Diego. During their season a number could be procured at any time by throw.

*Ueber die ersten Entwickelungsprocesse der Knochenfische. Zeitschr. f. Wissenseh. Zoöl., 1883.

†Beiträge zur Entwickelungsgeschichte der Knochenfische. Arch. Mikr. Anat. XxviII, 1886.

$\ddagger$ Le nova galleggianti e le larve dei Teleostei nel golfo di Napoli. Mitth. Zoöi. Stat. Neaple, viII, 1888.

\$ The Development of Osseus Fishes, I. Mem. Mus. Comp. Zool. 1885. 
ing the net from the wharf as far as it would reach and drawing it in again. They were first noticed April 18, 1889, when eight eggs were found. They soon became very abundant and remained so until July.

There is but a small water space in the egg membrane, and the germ lies at the end of the longer axis of the egg just beneath the micropyle.

The physiological axis of the egg, therefore, corresponds to its longer structural axis.

The fertilization and the earliest stages in the segmentation were not observed in any of the pelagic eggs. All the eggs found had evidently been deposited in the evening. The segmentation progresses rapidly, being completed in about eleven hours. At this time the blastoderm rests on the periblast only on its outer margins. The periblast dips deeply into the yolk, leaving a large, concavo-convex-shaped segmentation cavity, to the bottom of which cells from the blastoderm sometimes fall (Fig. 1). This is probably the stage termed the "blastula" by Ryder. Some time after the infolding of the margin of the blastoderm the segmentation cavity is almost entirely obliterated by the ingrowing cells. The inner margin of the embryonic shield reaches beyond the middle of the blastoderm, and by the time the blastoderm covers half the yolk the embryo extends entirely across the ectodermic end of the yolk (Figs 2 and 3). The anterior and posterior margins of the embryonic ring extend evenly over the yolk and the blastopore closes at the entodermic pole.

M. Kowalewski concluded, from several preserved oval eggs, that the posterior margin advanced but little, while the anterior edge moves over the greater portion of the egg, the blastopore closing near the ectodermic pole. It would seeem that such a closing of the blastopore would be somewhat precipitous after the embryonic ring had passed the entodermic pole of the egg. He has superimposed the stages in his possession in a single figure. The latest stage-one about corresponding to a stage intermediate between my Figs. 9 and 10 -he has drawn upside down, which would bring the closing of the blastopore about where the auditory capsule of my Fig. 10 comes to lie. His first two stages are either pathological (which would account for the eccentric positions of the blastoderm), or the blastodise in the species studied by him is normally placed to one side of the exact mechanical pole of the egg.

In the eggs observed by me the tip of the head soon comes to a state of rest while the posterior growing end of the embryo advances over the yolk.

The blastopore closes in about eighteen hours. Kupffer's vesicle disappears in about twenty-four hours. At the closing of the blastopore the embryo extends somewhat more than half way around the yolk.

The embryo hatehes in about forty-eight hours and measures 1.79 millimeters. The tail is sharply bent down over the yolk, making almost a right angle with the axis of the body, so that the vigorous 
motion of the tail causes the embryo to revolve around its snout as a pivot.

$\Delta t$ this time the lateral organs show as four or five hyaline projections on either side of the body. On treating the eggs with Perenyi's fluid just before hatching, the contents of these cells become granular. The embryo contracts and a slender thread, the nervus laterale, can be seen connecting them. Slender roots are also seen extending from these cells to the embryo.

The yolk is rapidly reduced in size and the embryo doubles its length in about twenty-four hours. The oldest larva examined is represented in Fig. 14, forty-eight hours after hatching.

Pigment does not appear in these eggs or larvæ during the time that they were examined.

In the segmented yolk these eggs agree with those of the shad and other physoclistic fishes.

\section{Stolephorus compressus (Girard).}

Girard, Pacific R. R. Survey, X, 336, 1859.

R. Smith '80; J. and G.' '80a., 457; id. '81, 37; id. '82, 276; R. Smith '85, July; E. and E., l. c., June, 1889.

Quite common, but not so abundant as ringens or delicatissimus.

Development of Stolephorus compressus.

(Plate x, Figs. 1-5).

The eggs of this species can readily be distinguished from other pelagic eggs. They are spherical, transparent, without oil globules, and with a totally segmental yolk. They measure 0.76 millimeter. A single egg of this species was found April 24 and is represented in Fig. 1. The next appearance of these eggs was on April 26, when two eggs were found, the one represented in Fig. 2 the other in Fig. 4. The one represented in Fig. 2 hatched in about sixty hours. The time required for hatching was considerably reduced in eggs found later, doubtless owing to the rise in temperature. More eggs were found on June 2, and from June 15 to 25 they were very abundant.

On hatching these fishes resemble the other species of Stolephorus, and but little difference can be made out between the species during the first twenty-eight hours after hatching. Up to this time no sign of pigment has appeared.

\section{SYNODONTID瓜.}

\section{Synodus lucioceps (Ayres).}

This species is never very abundant at San Diego and has not been recorded from here until the present year. It was first observed by me on September 14,1889, and it was caught with hook and line and with seines at an average of about one a day till the 17th of December. None were observed after that until February 11, 1890, when a single specimen was taken. It was most abundant during November. 


\section{SCOPELIDA.}

Three species of this family were taken at the Cortes banks and three in the neighborhood of San Diego. All were taken from the mouths of Rock Cod. They are not found in the regions inhabited by Rock Cod except on stormy days, and it is only during rough weather, therefore, that they can be procured. The explorations of the Albatross would seem to show that in deep water there lives still another series of this family.

The littoral species of this family, known from the Pacific coast of America, may be distinguished by the following key:

a. Lat. l. none. Greatly compressed. Seales crenulate......Tarletonbeania E. \& E. b. Origin of dorsal equidistant from tip of snout and base of caudal peduncle; ventrals reaching half way to 7 th anal ray; no spines on caudal peduncle; dorsal and ventral profiles equally arched. Tenia E.\& E.

$b b$. Origin of dorsal nearer snout than base of caudal; ventrals not reaching half way to vent; caudal peduncle with three spines above and below; ventral profile more strongly arched than dorsal profile.

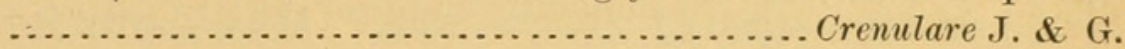

aa. Lat. 1. present.

c. Phosphorescent spots thetaform .................... Diaphus E. \& E. d. Pectorals small, not reaching ventrals, inserted low. D. 11. A. 12. Lat. 1. 34. Head $3 \frac{1}{2}$; depth 4. Snout blunt. Orbit 3 in head, $\frac{8}{4}$ in interorbital. Scales entire. A conspicuous phosphorescent spot before each eye.......................... Theta E. \& E.

cc. Phosphorescent spots normal.

$e$. Scales of lat. 1. enlarged .......................... . . f. A. 14 . lat. 1. 36. Eye 4 in head, 1 in interorbital. Head $3 \frac{1}{2}$. D. 13. Light gray, finely dotted with black. Deep forward, decreasing evenly to caudal peduncle, which is 2 in the greatest depth.....

ee. Scales of lat. 1. not enlarged.

Lucopsarum E. \& E.

g. Pectoral inserted high. Dorsal not longer than anal. Мүсторнuм Raf.

h. A phosphorescent spot at base of middle caudal rays. Pectoral narrow, reaching origin of anal. Ventrals to the vent.........

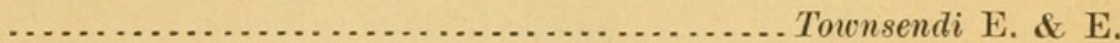

$h h$. No phosphorescent spot at base of middle caudal rays.

$i$. Pectoral not reaching second third of ventral. Ventrals to vent. Lat. 1. 42 ............................... Californiense E. \& E.

ii. Pectoral large, broad, reaching vent. Ventrals not to vent. Lat.

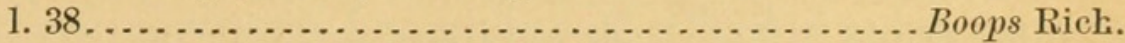

gg. Pectoral small, inserted low, the upper margin scarcely higher than origin of ventrals. Dorsal longer than anal. Eye 4 in head.. Catablemelia Brachychir E. \& E.

Tarletonbeania tenua Eigenmann and Eigenmann.

E. \& E., '90, 7 .

This species is at present known from a single well-preserved specimen taken off Point Loma. U. S. Nat. Mus. No. 41882.

E. \& E., '90, 4 .

Diaphus theta E. \& E.

This species is quite abundant. A single specimen was obtained off Point Loma, December 2, 18899, and a number of specimens on the 28th 
and 29th of January, 1890. It is known from the types only. U. S. Nat. Mus. Nos. 41914 and 41922.

In the structure of its phosphorescent spots it stands unique among the North American scopeloids.

\section{Stenobrachius leucopsarum E. \& E.}

E. \& E., '90, 4. Myctophum nannochir Gilbert.

This is the most abundant species found near Point Loma. Specimens can be procured almost any rough day from the mouths of Rock Cod. It has been procured on December 4 and 27, 1889, and on January 28 and 29, 1890. During the last two dates it was quite abundant. U. S. Nat. Mus. No. 41916.

E. \& E., ' $89,2$.

Myctophum townsendi E. \& E.

This appears to be the most abundant scopeloid on the Cortes Banks, where a number were obtained from the mouths of Rock Cod in July, 1889, just after a heavy "nor'wester." It is known from the types only. U. S. Nat. Mus. No. 41921.

E. \& E., '89.

Myctophum californiense E. \& E.

This species was procured with $M$. townsendi on the Cortes Banks. It is known from the types only. U. S. Nat. Mus. No. 41920.

Catablemella brachychir E. \& E.

E. \& E., ' 89,$3 ; i d$, '90.

This species is known from the specimens taken with the preceding two on the Cortes Banks. In general appearance it does not differ much from Myctophum. The position of the pectoral warrants, however, a generic separation. U. S. Nat. Mus. No. 41915.

$$
\text { SALMONIDA. }
$$

Salmo irideus Gibbons.

R. Smith, '80 (Pala); J. \& G., '81, 38; id., '82, 312; R. Smith, '85, July.

This is one of the three or four species of fresh-water fishes known from the western slope of San Diego County. It is abundant in the streams rising in Smith Mountain and emptying into the San Luis Rey River. It also occurs in the mountain streams east of San Quentin, Lower California.

\section{CYPRINODONTID E.}

\section{Fundulus parvipinnis Girard.}

Girard, Proc. Acad. Nat. Sci., Philad., 1854., 154, and Pacific R. R. Survey, x, 303, 1859; Giinther, Cat. Fish., vi, 319, 1866; Steind., Ichthyol. Beitr., v, 153, 1875; J. \& G., '80, 30; R. Smith, '80; J. \& G., '80a. 357; id., '81, 42; id. '82, 333 ; R. Smith, '85, July.

Very abundant in the bay of San Diego and Elsinore (fresh) Lake.

* Cyrinodon macularius Girard. Specimens of this species were collected by Mr. C. R. Orcutt on the Colorado Desert. Others were collected by Mr. F. Stephens. 
MURANIDA.

Sidera mordax (Ayres).

J. \& G., '80, 30; R. Smith, '80; J. \& G., '80a, 357; id. '81, 36; id, '82, 356. R. Smith, '85, July.

Not common. Very rare in the bay.

I have not collected this species in tide pools. It seems to be common on rocky places of the ocean beach. It was taken in the bay on May 1 and October 15, 1889.

\section{BELONIDA.}

Tylosurus exilis (Girard).

Girard, Proc. Acad. Nat. Sci., Philad., 1854, 149, and Pacific R. R. Survey X 158, 1859; Guinther Cat. Fish vi, 238; J. \& G., '80, 30; R. Smith ' 80 ; J. \& G. '80a, 357; id. :81, 43; id., '82, 374; R. Smith, '85, July.

This species is very common in San Diego Bay during A pril and May, when it swims in schools on the surface. Schools are frequently seen flanking schools of Anchovies. Ripe or nearly ripe eggs were obtained in the middle of April, and in May they flow quite freely. (J. \& G. give the spawning season as August.) I have not been able to artificially fertilize the eggs nor have I found them developing naturally. The species is very rare in winter, I did not notice it later than October. Jordan \& Gilbert procured a specimen in January.

On account of its "green backbone" it is not used as food. The egg is large, amber colored, $2.4 \mathrm{~mm}$. in diameter. The zona radiata is provided with long tapering filaments set in basal sheaths.

\section{R. E., Am. Nat. 1891,59 .}

\section{Scomberesox brevirostris Peters.}

One specimen of this species was procured for me by Mr. Medina during the summer of 1890 .

\section{Hemirhamphus rosæ Jordan \& Gilbert. Sworrifish.}

J. \& G. '80, 29; id., Proc. U. S. Nat. Mus., III, 1880, 335; R. Smith, '80; J. \& G., '80a, 357; id., '81, 43; id., 82, 376; E. Am. Nat., Feb. '91.

This species is common in the bay throughout the year. Like its relative, Tylosurus exilis, it swims in schools of about a dozen on the surface during the early portion of the year and during summer. During the latter part of summer and during fall it is not seen, living in deeper water. We have seen schools as early as January 17.

It probably spawns early in the year. Young were procured with the surface net during April and May.

\section{Exocœtus californicus Cooper.}

R. Smith, '80; J. \& G., '80a, 357; id., '81, 42; id., '82, 379; R. Sinith, '85, July. E. \& E., Notes from San Diego Biol. Lab., I, 4, 1889.

This species is not uncommon off Point Loma and on the Cortes Banks during summer. It does not enter the bay and is not caught for the market. 
SYNGNATHIDA.

I have little to say concerning the members of this family. They are always very abundant, but I have observed them only once or twice while with the seiners, and while skimming for pelagic eggs.

\section{Siphosotma punctipinne (Gill).}

Gill, Proc. Acad. Nat. Sci., Philad., 1862, 283; J. \& G., '81, 69; id., '82, 385; R. Smith, '85, June.

Only the types known.

\section{Siphostoma auliscus Swain.}

R. Smith, '85, June.

Common.

Siphostoma leptorhynchum Girard.

Girard, Pacific R. R. Survey, x, 345, 1859. J. \& G., '80, 23; R. Smith, '80; J. \& G., '80a, 453; July, '81, 69; id., '82, 384; R. Smith, '85, June.

This is by far the commonest species of pipefish in the bay. Several are always taken in summer with the dredge, while the seine always brings them.

\section{Hippocampus ingens Girard.}

Girard, Pacific R. R. Survey, x, 343, 1859. J. \& G., '80, 23; R. Smith, '80; J. \& G., '80a, 453; id., '81, 69; id., '82, 386; R. Smith, '85, June.

We have never taken this species and have seen no specimens which certainly came from San Diego. It is said to occur about the Coronado Islands.

\section{GASTEROSTEID $Æ . *$}

\section{Gasterosteus microcephalus Girard.}

R. Smith, '85, June.

This species has not been observed by us during the year. It was taken by Rosa Smith in Wildeat Cañon, a tributary of the Tia Juana River.

\section{MUGILIDA.}

Mugil cephalus L.

Steind., Ichthyol Britr. III, 58, 1875; J. \& G., '80, 29; R. Smith, '80; J. \& G., '80a, 457; id., '81, 76; id., '82, 403; R. Smith, '85, July.

This species becomes abundant about the middle of February. It then enters the bay and ascends the swollen coast streams. The exact time of spawning has not been determined. One ripe female was reported to us on December 10 by a fisherman, who had never noticed it with eggs at other times. The young remain in the bay throughout the year, and are found chiefly in the sloughs of mud flats.

* Autorhynchus flavidus (Gill) has heen described to be by fishermen. I have not seen it. 
ATHERINIDÆ.

Menidia tenuis (Ayres).

J. \& G., '80, 29; R. Smith, '80; J. \& G., '80a, 456; id., '81, 43; id., '82, 405; R. Smith. '85, July; E. \& E. '89a.

This species was observed from August to December. Jordan \& Gilbert procured it in January. We have not seen it during spring and summer. It is not frequently brought into the markets.

\section{Atherinopsis californiensis Girard. (Plate XIII.)}

Girard, Pacific R. R. Survey, x, 103, 1859. J. \& G., '80, 29; R. Smith, '80 ; J. \& G., '80a, 456; id., '81, 44; id., '82, 409; R. Smith, '85, July; Eigenmann, Am. Nat., March, 1889.

During its season this is one of the important food fishes of San Diego. It reaches San Diego the latter part of August, although but few enter the bay before November. It becomes abundant in October and remains so through January. The exact date of its disappearance has not been determined; large individuals have been seen as late as February 24. Some females are with ripe spawn as early as the beginning of November and others do not spawn till the middle of February, and farther north the spawning season is still later. Ripe females have been observed by us at San Pedro in March, and others in the San Francisco markets as late as May. During January and February the young of this species occur in enormous numbers along the muddy beaches of the bay, and a pail of water dipped at random frequently contains a dozen or more of them.

I have succeeded in artificially fertilizing this species, but have not succeeded in hatching the eggs. I have not found the eggs in their natural position. The stages reached by the eggs artificially fertilized and the larvæ dredged enable me to give a tolerably complete outline of the embryonic and larval stages of this species.

The eggs and milt of this species were taken from living fish and artificially fertilized at 4 p. m., December 31, 1889 .

The zona radiata of this, as in all other species of the Atherinidx, is provided with long filaments which taper slightly toward the tip; at the base they are expanded into a broad hollow disk, a projection of the zona fitting into the hollow of the filament. (Pl. XIII.) There are about ten of these filaments, and they are scattered evenly over the whole surface of the zona. In the green eggs they are closely coiled as parallels of latitude, being less regularly coiled at the poles. In the ripe eggs they are uncoiled, and the green ones can therefore be readily separated. At the time the eggs are deposited a large number of globules are scattered over the yolk; these, however, soon collect in two groups, one at the top of the egg and one at or near the entodermic poles.

Very frequently the eggs assume such a position that their axes are

Proc. N. M. $92-10$ 
horizontal. The micropyle can, in these cases, most usually be found and the formation of the blastodisk observed.

In pelagic eggs, in which the blastodisk invariably forms on the lower surface of the yolk, its formation might in part be explained by gravitation; not so in Atherinopsis and Ciupea, where it forms at the side of the yolk. In later stages it is seen that this is the normal position of the germ, for even if one succeeds in bringing it to the top of the egg, the egg slowly rotates, the oil globules changing position until the germ lies again at the margin. The process of the formation of the germ differs considerably from that in Clupea. After the water space is formed a contraction begins near the ectodermal pole and travels to that pole. This is repeated rythmically. One series or one of the waves is represented in Figs. 2-7. In Fig. 2 the contraction has begun; in Fig. 5 it has reached its culmination, and in Fig. 7 it has ended and another is about to begin.

The first cleavage is completed after about three hours and twentyfive minutes from fertilization; twenty minutes afterward four cells are formed.

The sixteen-cell stage is reached in four hours forty-five minutes; thirty-two cells are formed five hours and ten minutes afterward. The first horizontal furrow was noticed after six hours, and the "blastula" (Fig. 12) after twenty-eight hours. This figure is seen but a very short time; it is apparently formed by the sinking of the yolk below the center of the blastoderm. Cells from the overlying blastoderm frequently fall to the bottom of this segmentation cavity. The cavity is apparently obliterated by the settling down of the cells overlying it; immediately after its disappearance the blastoderm spreads and its margins begin to be infolded. At this stage periblast nuclei are very abundant and extend over half the yolk; twelve hours afterward they have apparently decreased in number and are much larger in size.

The blastopore closes after about eighty hours. Kupffer's vesicle appears on the fourth day, the heart on the seventh; on the twelfth the embryos move vigorously; on the sixteenth day pigment spots appear on the top of the head and along the median line of the back. At this stage the embryos died, but the further developement may be gathered from the accompanying figures of larvæ procured by skimming with the surface net.

Atherinops affinis (Ayres). Top smelt.

J. \& G. '80, 29; R. Smith '80; J. \& G. '80a, 456; id. '81, 43; id., 82, 409.

This species is found in San Diego Bay throughout the year. It is abundant through winter and spring, but is not esteemed as highly as the smelt. Large numbers are taken with seines. They spawn in May and June. The larvæ are abundant in the bay, but its development has not been traced. From their habit of keeping near the surface, especially surrounding offal, they are termed Top Smelt. 
SPHYRANIDA.

Sphyræna argentea Girard. Barracuda.

Girard, Pacific R. R. Survey, x 39, 1859; Steind. Ichthyol., Beitr., vII, 1, 1878. J. \& G., '80, 29; R. Smith, '80; J. \& G., '80a, 456; id. '81, 44; id. '82, 41; R. Smith, '85. E. Zoe, April, '90.

This is one of the most important food fishes of the whole of southern California. In summer it is abundant on the whole coast of California from Monterey southward, but it is probably more abundant southward than in the neighborhood of Monterey. During the winter it disappears from the coast of California, but is taken on the coast of Lower California. It probably migrates bodily southward, but stray individuals undoubtedly remain in the waters of southern California throughout the year, for two or three days of exceptionally fine weather invariably brings them into the market. It is likely that these stray individuals live in deep water during the winter, and come to the surface on bright days. It is quite possible, though not probable, that a great part of those disappearing descend to deeper water. The fact that they are taken only by the troll or by gill nets sufficiently explains why they should not be caught in deep water.

Their movements have been watched through an entire season at San Diego, and as these observations may be valuable to serve as a basis for comparison, they may be stated here.

During January, 1890, none were seen. During February, 1890, four were taken on the 7 th, one on the 11th, and two on the 28th. All these dates were at the end of a succession of days of exceptionally fine weather. On March 1, 1890, two were taken. On March 26, 1889, a few were caught, and on the following day they were abundant and remained so, with occasional lapses, throughout the summer. At the beginning of July they were with ripe spawn.

During September few were taken, but on the 29th, 30th, and 31st of October they were again abundant. On November 6 one was taken, on the 7 th another, on the 15th one young one was caught with a hook in the bay, and on the 18th another young one was brought from off Point Loma. On the 16th of December, one young individual, evidently of the preceding summer's spawning, was taken in the bay, and on the 30th a large one was caught off Point Loma.

The adult never or very rarely enter the bay, but in spring the young, those not yet a year old and measuring about a foot in length, enter the bay in large schools, and are then destroyed in quantities with seines or Chinese bag nets.

About San Diego the troll is the only means used in eatching them. It is simply a piece of white rag, or, more commonly, a fragment of bone, to which a hook is lashed. One or more of these is dragged behind a boat made usually after the pattern of the Columbia River salmon boats. The amount of the eatch depends largely on the wind. 
slack wind, even when barracuda are abundant, briags but few fish. The largest eatch reported for a single day is 1,100 by one boat with two men. Rarely more than 40 are taken. They average from 6 to 12 pounds, and from $2 \frac{1}{2}$ to 4 feet in length, and retail at 10 cents apiece. Large numbers are salted and dried.

About Monterey they are taken with the gill net. In 1890 the first individuals reached Monterey on March 10.

Like most of the surface and shore food fishes the barracuda feeds chiefly on the anchovy (Stolephorus ringens).

Among Mrs. Eigenmann's notes is the following: S. argentea 8 to 12 inches long, abundant about San Diego steamship wharf, where they were taken by trolling, May 17, 1885.

\section{ECHENEIDID $Æ$.}

E. \& E. ' $89 \mathrm{a}$.

\section{Remora remora (Linnæus).}

This species is common in summer when sharks abound. It is usually attached to Sphyrna zygana. On other sharks it has not been observed.

\section{XIPHIID正.}

(Xiphias gladius Linnæus).

E. \& E. '89a.

This species has never, to my knowledge, been brought into the markets of San Diego. I have observed it on the Cortes Banks, as well as farther northward.

\section{SCOMBRIDE.}

\section{Scomber colias Gmelin.}

Steind. Ichthyol. Beitr. III, 53, 1875; Scomber pneumatophorus, J. \& G., '81, 45; id. ' 82 , 424; R. Smith, ' 85 ; E. \& E. ' 89.

This species is quite abundant at San Diego. During August several fishermen reported large schools off Point Loma, and the bay was literally full of tinkers. They are caught in seines and with hook and line. One boy caught, in the latter way, one hundred and eighty tinkers in one hour. The tinkers enter the bay in August and become very abundant in September and October. They decrease in number during December. During February, 1890, none were seen, but stragglers were taken in March and May, 1889.

At present this fish is of little importance at San Diego.* Very few large ones are taken and those are usually caught while fishing for other fish. The tinkers afford sport to many idlers on the wharves, but otherwise little use is made of them. At Monterey they are abundant during June, and at times bring a high price. They are taken with the gill net at Monterey, a mode of fishing scarcely in use at San Diego.

\footnotetext{
* Since this was written a cannery was established and many fishermen make it a business to eatch mackerel with hook and line off Ballast Point.
} 
Green eggs of August 16 measure $0.66 \mathrm{~mm}$. They have an ambercolored oil globule $0.24 \mathrm{~mm}$. in diameter.

Sarda chilensis (Cuvier \& Valenciennes).

J. \& G. ' 80,27 ; R. Smith ' 80 ; J. \& G., ' $80^{\text {n }}$, 456, id. 81,45 ; id. '82, 428; R. Smith '\$5; E. \&. E. '89. Girard, Pacific R. R. Survey, x. 106, 1859 (as Pelamys lineolata).

This species is very common off Point Loma. Many more are taken than can be disposed of fresh. It is usually found in schools and apparently migrates with the barracuda. It is probably found here throughout the year, but none were recorded in April or June. It was very abundant from July to December, 1889. Toward the latter and early part of the year the young occasionally enter the bay. On January 4,1890 , a few were taken and one young one on the 30 th. On February 28, six were taken; during March of 1890, four small ones were taken on the 1st, while they were abundant and with free flowing milt on the 27th of March, 1889.

E. \& E., '89.

\section{Orycnus alalonga (Gmelin).}

This species is abundant off the coast in summer. It is never brought into the market.

\section{Gymnosarda pelamys (Linnæus).}

E. \& E., '90, 8.

This is said to be common off Point Loma, but only on two occasions were any brought into the San Diego market, $i$. e., on October 31 and December 15, 1889.

Trachurus picturatus (Bowdich).

R. Smith, '85; E. \& E., '89.

This species is never abundant at San Diego. The first ones of 1889 arrived on July 3 , and while it was sometimes quite common, especially among the catch with hook and line on the wharf, it never reached any economic importance. On January 4, 1890, a few young ones were taken in the bay; later it was not observed. It is found in San Francisco in May, and large ones are sold in September.

\section{Caranx chrysus caballus Giinther.}

Trachurus boops Girard, Pacific R. R. Survey, x, 108, 1859.

This species is recorded from San Diego by Girard. We have not seen it.

\section{Seriola dorsalis Gill. Yellow tail.}

R. Smith, '80; J. \& G., '80a, 456; J. \& G., '81, 46.

This large species is quite abundant off Point Loma, but it rarely enters the bay. It is taken by the barracuda boats. It is not very highly esteemed and never brings over 25 cents apiece. It arrived. 
in 1889, on April 30, and was found throughout the rest of the year. It was quite abundant on Cortes Banks in August, but no use was made of it except as bait. It migrates southward towards winter and decreases in abundance during November. Stragglers like those of the Spanish mackerel enter the bay late in the season. During December, 1889, it was taken on the following dates: 11th, 16th, 19th, 30th. On the 11th, one was taken in the bay; on the 19th, one was taken off Point Loma, and on the 30th, three were taken. During January and February of 1890 none were seen.

Jordan \& Gilbert (1881) state that it spawns in July and August.

\section{STROMATEIDA.}

Stromateus simillimus (Ayres). Pompano.

R. Smith, '80; J. \& G. '80a, 456; id., '81, 46; id., '82, 451; R. Smith, '85, July.

Though common at times this fish is not of such importance here as at San Francisco. In San Francisco it brings from 25 cents to $\$ 1.25$ per pound. In San Diego it sells at 3 cents.

It arrives at San Diego in May, the first ones observed being on May 16. Another one was taken on June 1. This was a male with ripe milt. During August and September it was quite abundant, being: chiefly taken with hook and line off wharves. It is not caught outside. During December only a few young ones were caught. During January of 1890 a few more and on February 21 one more young one was taken.

\section{SERRANID $A$.}

Paralabrax clathratus (Girard). Kelp Bass; Sand Bass.

Girard. Pacific R. R. Survey, Vol. x, 35, 1859; Steind., Ichthyol. Beitr., III, 1, 1875 ; J. \& G., '80, 27; R. Smith, '80; J. \& G., '80a, 456; id., '81, 47; id., '82, 535 ; R. Smith, '85, July; E. \& E., '89.

The young of this species are abundant in the bay. The old are rarely, if ever, seen in the bay. They are taken in 15 to 50 fathoms of water with Rock Cod. It is not so frequently brought into the markets as the other species of the genus.

\section{Paralabrax maculofasciatus (Steindachner). Rock Bass.}

Steindachner, Ichthyol. Beitr., III, 1, 1875; J. \& G., '80, 27; R. Smith, '80; J. \& G., '80a, 456; id., '81, 416; id., '82, 536; R. Smith, '85, July; Am. Nat., Feb. 1891, figures.

This species is a permanent resident in the bay. It was especially abundant during fall and early winter. The eggs of this species, like those of the next, are pelagic, colorless, transparent, 0.75 to 0.81 millimeter in diameter. There is in each case a single colorless globule.

The eggs of Paralabrax maculofasciatus were first observed on June 25. They were next observed on August 10, and were occasionally 
found throughout the remainder of August. The blastopore closes in about eighteen hours, and the embryo is freed in about thirty-eight hours. On hatching the embryo measures 1.7 millimeters, the yolk sack 0.65 millimeter.

At the time of the closing of the blastopore a few color cells are scattered over the yolk near the oil globule; a yellow pigment is pretty evenly distributed along the sides of the embryo. This yellow pigment shortly becomes collected in well-defined areas along either side of the embryo, and at the time of hatching there is a mass of cells at the snout, one behind each eye, one behind each auditory capsule, four just behind the yolk sac, and two or three on the anterior half of the tail. A few black cells are scattered along the back. These cells soon become dendritic to such an extent that there is little similarity between the larva at hatching and twelve hours afterward.

At the time of hatching the larva measures 1.7 millimeters, the yolk sac 0.65 millimeter. The oil globule, as in nebulifer and atrarius, is embedded in the anterior end of the yolk.

The color cells in the case of P. maculofasciatus do not, as in the cases of Scicna and Hypsopsetta, all become free. Sketches of this species were made a few moments apart (see Am. Nat., February, 1891). The color cells are first noted when the gastrula covers about two-thirds of the yolk. At this time no pigment is deposited in them and only those which are freed from the embryonic shield can be distinguished. Very few of the cells ever become freed from the shield and all those that are freed are destined for the oil globule. The great majority of color cells remain attached to the margins of the shield. They migrate, however, as is seen in their shortly aggregating in definite regions of the body.

\section{Paralabrax nebulifer (Girard). Rock Bass.}

Steindachner, Ichthyol. Beitr., III, 1, 1875; R. Smith, '80 ; J. \& G., '80a, 456; id., '81, 47; id., '83, 536; R. Smith, '85, July ; E. Am. Nat., Feb. 1891, figures.

This species is found in the bay with the preceding.

But two eggs of this species were observed, one on June 25 and the other on August 26. In this species only black pigment cells are formed. The embryo is freed from the membrane in thirty-six hours and measures 22 millimeters; the yolk sack measures 1.3 millimeters. On the body the black cells are confined to the dorsal surface, while on the tail they are more uniformly distributed. The oil globule is situated at the anterior end of the yolk.

\section{Stereolepis gigas Ayres. Black Sea Bass.}

J. \& G., '80, 27; R. Smith, '80; J. \& G., '80, 456; id., '81, 47 ;id., '82, 531; R. Smith, '85, July; E. \& E., '89.

I am not certain whether this species is migratory or not, but am inclined to believe it is. It is not very abundant, but a number can always be taken, at least in certain seasons, by using the proper gear 
and bait. They seem always to accompany the white fish and these fish are consequently used as bait. Several were brought into the market, but the dates were not kept. In July several were taken on Cortes Banks while others were taken near Point Loma in October and November, 1889.

\section{SPARIDA.}

Xenistius californiensis (Steindachner). Raspers.

Steind. Ichthyol. Beitr. III, 3, 1875; E. \& E. '89a.

Until recently this fish was very rare. On May 20 one was taken in a seine, and the fishermen stated that it was occasionally found. During August and September large numbers were caught with hook and line. The last one was taken November 9.

\section{Anisotremus davidsoni (Steindachner).}

Steind. Icthyol. Beitr. III, 6, 1875; R. Smith '80; J. \& G. '80a, 456; id. '81, 47; id., '82, 531; R. Smith '85, June.

This species is found in the bay from April to November. None were observed between November 9,1889 , and March, 1890. The first one of 1889 arrived April 20. It is quite common during its season, although few records were made of it. It is a food fish of some value and is caught in seines and with hook and line.

\section{Girella nigricans (Ayres).}

J. \& G. '80, 28; R. Smith ' 80 : J. \& G. '80a, 456; id., '81, 47; id., '82, 560; R. Smith '85, June; E. \& E. '89.

This is a permanent resident among the rocks of the ocean shore, and just within the entrance of the bay. It is rarely taken by the seiners on account of the impossibility to draw the net where they reside. On April 17 a number of ripe males were taken.

\section{Cæsiosoma californiense (Steindachner).}

Steind. Ichthyol. Beitr. III, 19, 1875; R. Smith '80; J. \& G. '80, 456; id., '81, 47; id. '82, 562; R. Smith, '85, June.

This species is very probably a permanent resident. It is very rare. Those seen were taken among the piles of the ferryslips and wharves, and if this should be their habitual abiding place the fact that they are not more frequently taken would be explained. It is of no economic importance. On May $3 \mathrm{~d}$ a male with ripe milt was procured.

\section{SCIÆNID无.}

Roncador stearnsi (Steindachner).

Steind. Ichthyol. Beitr. III, 22, 1875; J. \& G. '80, 28; R. Smith '80; J. \& G. '80a, 456 ; id., ' 81,49 ; id., ' 82,572 ; R. Smith ' 85 , June.

This is an important food fish which is only occasionally absent from the bay. During January, 1889, none were taken in the bay, 
while on December 18th, 1889, 400 pounds were caught with one haul of the seine, and on January 10, 1890, they were again abundant. During the summer they do not go in schools. Those caught on December 18, 1890, were said to have been burrowing with their blunt snouts for a small mollusk (Empidonax) on which they largely subsist.

\section{Sciæna saturna (Girard). The Croaker.}

Girard, Pacific R. R. Survey x, 98, 1859; J. \& G. '80, 28; R. Smith '80; J. \& G. '80a, 456; id., '81, 49; id., '82, 572; R. Smith, June, '85.

This is an important food fish. It is migratory. The males, which are then quite black, enter the bay as early as January (28 and 29,1890), and by the middle of February and March it is common. The last one was observed September 24 .

Ripe males were seen March 27 and ripe females the two months following. Eggs were skimmed from May 2. Evenings while skimming over the breeding grounds their frog-like croaking could be heard on all sides.

The egg's of this species are remarkably like those of a flounder (Hypsopsetta) and it is only after a time that they can certainly be told apart. It is not unlikely that several species of pelagic eggs have been confounded with this one, as eggs supposed to be these were taken from May to the middle of August. If this should be the case they probably belong to the other species of this family, the eggs of which have not yet been described.

The eggs are transparent, 0.78 millimeter in diameter, and have from two to eight oil-globules, which, in late stages, are united into one. The eggs can best be distinguished from those of Hypsopsetta by the method of the formation of the chromatophores. These are formed along the entire embryonic ring in this species and appear quite early.

The time required for hatching, if indeed all the eggs referred to this species belong to it, varies greatly with the temperature, the longest time being forty-eight hours, the shortest eighteen. In those hatching earlier the yolk is not as much reduced as in the others, and the tail is not quite as long.

The young of this species were figured in the American Naturalist for February, 1891.

\section{Genyonemus lineatus (Ayres).}

E. \& E., ' 89 a.

This species entered the bay in large numbers in December (27), 1890. During the latter part of January ripe females were obtained. None were seen after February 3 . The eggs are pelagic 0.71 millimeters in diameter and have an oil globule 0.18 millimeters in diameter. It is caught with the seine and with hook and line. 


\section{Umbrina roncador Jordan \& Gilbert.}

R. Smith, '80 (as U. xanti); J. and G., '80a, 456; id., '81, 48; id., '82, 576; R.

Smith, '85, June.

This species was abundant in the bay at various times between May (25) and January. It is taken with the seine.

Menticirrhus undulatus (Girard).

Girard Pacific R. R. Survey x, 101, 1859; Steind, Ichthyol. Beitr. III, 21, 1875; J. \& G., '80, 28 as (M. elongatus); R. Smith, '80; J. \& G., '80a, 456; id., '81, 48 ; id., '82, 578; R. Smith, '85, June.

Migratory. This species was, with the preceding, abundant at times between July and January. On January 9, 1890, one was taken in the bay; on February 11 another. On February 19, 1890, a boatload of this species and of Cynoscion parvipinne was brought by Chinese fishermen from lower California.

\section{Cynoscion nobile (Ayres).}

R. Smith, '80; J. \& G., '80a, 456; id., '81, 48; id., '82, 579; R. Smith, '85, June.

Migratory. This species entered San Diego Bay in April (26) and remained till November. Those in the bay are all young specimens less than 600 millimeters long. They are taken with the seine and with hook and line. Larger ones, reaching 1.2 meters, are occasionally (November 7,1889, ) taken off Point Loma. Either this species or the next were reported to have ascended a stream produced by the waste water of the Sweetwater dam. It was brought to the San Francisco market May 2, 1890.

\section{Cynoscion parvipinne Ayres.}

J. \& G., '80, 28 as (C. magdalena) ; R. Smith, '80; J. \& G., '80a, 456; id., '81, 48; id., '82, 580; R. Smith, '85, June.

This species probably enters the bay with the preceding species, being also migratory. The first individual was seen March 21, 1889, the last December 30.

\section{Seriphus politus Ayres.}

R. Smith, '80; J. \& G., '80a, 456; id., '81, 48; id., '82, 582; R. Smith, '85, June.

Migratory. This species is said by Jordan to be abundant during summer about Santa Cruz. It does not reach San Diego till September $(10,1889)$, and is abundant at least till March. The time of its disappearance has not been determined, as it was not seen in the spring of 1889.

\section{GERRID正.}

Gerres cinereus Walbaum.

R. S. E., Am. Nat., 1891, 156.

One specimen of this species was taken by Mr. Medina during the summer of 1890. Mr. Medina preserved the specimen for me, but the exact date was not kept. 


\section{EMBIOTOCIDA.}

The members of this family are probably all permanent residents. From their abundance they are important fishes. Those taken outside are, as a rule, of much better flavor than those taken in the bay. Some of the species habitually live in the surf of the ocean beaches, while others habitually live in the bay.

Since their discovery these fishes have been of great interest on account of their most pronounced viviparity. Several papers have dealt especially with the embryology, but no one has hitherto been able to study the early stages.

The early stages of all of them occur in December or thereabout. The older individuals are with ripe eggs earlier in the season than the younger, so that in species like Amphistichus argenteus where there are three distinct sizes of individuals, there are three distinct periods when the eggs mature, with an interval of about a month between two of these periods.

The embryology of the members of this family will be treated in a separate paper.

Owing to the fact that these fishes are permanent residents, few notes on their occurrence were made. Some are always found in the market, and many are thrown away when caught.

Abeona minima (Gibbons.)

J. \& G., '80, 28; R. Smith, '80; J. \& G., '80a, 456; id., '81, 51; id., '82, 587; R. Smith, '85, June.

This species is very abundant in the eel grass near tide marks in tlie bay. The females are much larger than the males but none reach a size to warrant bringing them to the market.

The eggs of this species can be procured in December, January, and February. With those of cymatogaster they are the smallest fish eggs known, the yolk being scarcely developed.

\section{Brachyistius frenatus Gill.}

R. Smith, '85, June.

Very rare, only a single specimen seen (May 29, 1890).

\section{Cymatogaster aggregatus Gibbons. Shiner.}

J. \& G., '80, 28; R. Smith, '80; J. \& G., '80a, 456; id., '81, 51; id., '82, 590; R. Smith, '85, June; Eigenmann, Am. Nat. Mch. 89, 107; E. \& E., West Am. Scientist, June, 1889.

This is even more abundant than Abeona minima. It is found with it, but also along the beaches of the bay and about the piles of wharves, especially during the breeding season. It is rarely brought into the market, and then only when mixed with other species. 
Hyperprosopon argenteum Gibbons. Wall-eyed Pereh.

J. \& G., '80, 28 (as Hyperprosopon arcuatum); R. Smith, '80; J. \& G., '80a, 456; id., ' 81,50 ; id., '82, 591; R. Smith, '85, June.

Very abundant in the bay; it is caught with seines and frequently brought to the market; but little esteemed, and is of little economic inıportance.

\section{Holconotus rhodoterus Agassiz.}

Girard, Pacific R. R. Survey, X, 195, 1859; E. \& E., 90, 9.

Only a single specimen taken. It was found with $A$. argenteus in the ocean surf, January 10, 1890.

\section{Amphistichus argenteus Agassiz. Surf Perch.}

J. \& G., '80, 28; R. Smith, '80; J. \& G., '80a, 456; id., '81, 50; id., '82, 593; R. Smith, '85, June.

This species is one of the most abundant. It never enters the bay, being always found in the surf of the ocean beaches. It is the best flavored of the perches but is rarely caught for its own sake. When the smelt (Atherinopsis californiensis) arrives and before it enters the bay the fishermen seine for it on the ocean beaches and frequently catch quantities of this species. At other times of the year it is not found in the markets. Those caught could readily be divided into three grades, according to their size. The largest ones contained developing eggs the middle of November, the next in size the middle of December and the third were not yet mature when they stopped coming into the market the 7 th of January.

This species is frequently eaught with hook and line in the surf; the great bulk of those so caught are males. They feed on the crustaceans which burrow in the sandy beaches and follow the breakers to procure their food.

This is the most prolific of the species found at San Diego. It contains as many as fifty young, while the other species would scarcely average more than twelve.

R. Smith, '80.

$$
\text { Hypsurus caryi (Agassiz). }
$$

This species has not been observed by'me.

\section{Embiotoca jacksoni Agassiz. Black or Blue Perch.}

Girard, Pacific R. R. Survey, X, 171 and 173, 1859 (as E. cassidii and E. webbi); J. \& G., '80, 28; R. Smith, '80; J. \& G., '80a, 456; id., '81, 50; id., '82, 595; R. Smith, '85, June.

Very common in the bay. Not very highly esteemed, and of no great economic importance.

Phanerodon laterale Agassiz.

Girard, Pacitic R. R. Survey, X, 176, 1859 (as E. ornata); R. Smith, '85, June. - Very rare. 
Phanerodon atripes Jordan \& Gilbert.

E. \& E., 89a.

Only one specimen known; from the Cortes Banks. It is the commonest species of Monterey Bay but does not reappear on the coast to the south, between Monterey and the Cortes Banks.

E. \& E.. '89.

Phanerodon orthonotus E. \& E.

Only one specimen known; from the Cortes Banks.

Phanerodon furcatum Girard.

J. \& G., '80, 28; R. Smith, '80; J. \& G., '80a, 456; id., '81, 50; id., '82, 596; R. Smith, '85, June.

One of the commonest speciès in the bay and not rare on rocky places of the ocean coast. On account of its exterior appearance it is more highly prized than $E$. jacksoni, though scarcely a better fish. It is almost daily brought into the market, especially when flounders, the various bass and the various croakers are scarce.

E. \& E., '89a.

Rhacochilus toxotes Agassiz.

Rare, or else living in places where little fishing is done. It was noticed once during February.

E. \& E. '90, 9 .

\section{Damalichthys argyrosomus Girard.}

This species was moderately abundant between November and March. It was not seen during summer.

\section{LABRID A.}

\section{Trochocopus pulcher (Ayres).}

J. \& G., '80, 29; R. Smith, '80; J. \& G., '80a, 455; id., '81, 51; id., '82, 602; R. Smith, '85, June; E. \& E., '89.

This species is very abundant in all rocky places of moderate depth outside the bay. It never enters the bay. Large quantities are sometimes dried by the Chinese but otherwise it is of little importance. It is a rather coarse fish and on account of its uncouth appearance it is not in general favor.

It is abundant on Cortes Banks, and a quantity was salted by the Azalene.

\section{Platyglossus semicinctus (Ayres).}

Steind. Ichthyol. Beitr., V., 151, 1876; R. Smith, '85, June; E. \& E., '89.

Not common, and but rarely entering the bay. It was noticed but once or twice in the market.

Ripe eggs were obtained in mid August. They measure .66-.70 millimeters. They are transparent, and possess a single oil globule .14-.16 millimeters in diameter.

\footnotetext{
* This species is in all probability identical with $P$. atripes.
} 
Pseudojulis modestus (Girard).

Girard, Pacific R. R. Survey, X, 164, 1859; R. Smith, '85, June; E. \& E., '89.

Common in the kelp and generally outside. It rarely, if ever, enters the bay, and is rarely brought to the market. It is quite abundant at Cortes Banks, and is not an unimportant item of the food of larger fishes.

\section{POMACENTRID A.}

\section{Pomacentrus rubicundus (Girard).}

Girard, Pacific R. R. Survey, X, 161, 1859; R. Smith, '80; J. \& G., '80 a, 455; id., '81, 52 ; R. Smith, Proc., U. S. Nat. Mus., 1882, 652; J. \& G., '82, 610; R. Smith, '85, June.

Common at rocky ocean beaches. The adult of this species has never been seen in the bay. A few young, in which the bright blue had almost all given place to the bright red of the adult, were taken in the bay and held at fabulous prices. It is not used as food, the only place where they abound being reserved, so visitors may enjoy seeing them. Rosa Smith records it (unpublished notes) as being caught in lobster pots.

\section{Chromis punctipinnis Cooper.}

R. Smith, '80; J. \& G., '80a, 455; id., '81, 52; id., '82, 611; R. Smith, '85, June, E. \& E., '89a.

Seen but once, the single specimen taken from the stomach of a rock cod caught on Cortes Banks.

\section{EPHIPPID Æ.}

Chætodipterus faber zonatus (Girard).

Not seen by us nor at any time by Rosa Smith.

\section{LATILID $Æ$.}

Caulolatilus princeps (Jenyns). The Whitefish.

J. \& G., '80, 27 ; R. Smith, '80 (as C. anomalus); J. \& G., 80a, 455; id., '81, 53; id., '82, 625; R. Smith, '85, June; E \& E., '89.

This is probably a permanent resident. The fishermen say that winter is their principal season, though the catch during the past winter was light. It was common on Cortes banks during July and August, and during the first half of October off Point Loma. But few were taken in September and December, but during November and January it was again abundant. During April, May, and June I did not notice it, a fact which does not prove its absence, however.

The majority of those caught are sold fresh. The Azalene salted many. For some reason the flesh of this fish is frequently bitter and disagreeable and possesses a peculiar smell when quite fresh. The fishermen attribute it to the breaking of the gall-bladder in cleaning. I have proved that this is not the case. 


\section{GOBIID \&.}

The members of this family are all small and not at present used for food by man in the San Diego region. They play a most important role in fish economy, since, next to the species of Stolephorus, they probably furnish the largest share of food for the fishes of the bay. The species have been discussed in Zoe for May, 1890.

\section{Gobius nicholsi Bean.}

I have not taken this species. Dr. Gilbert informs me that it is quite abundant in deep water off Point Loma.

\section{Lepidogobius gilberti E. \& E.}

E. \& E., Proc. U. S. Nat. Mus., 1888, 464 ; Eigenmann, Zoe, May, 1890.

This species is less abundant than the preceding, with which it is sometimes associated. Most of the specimens known were dug out of the sand near La Playa. It spawns early in May.

\section{Lepidogobius y-cauda (J. \& E.). (Plate xIv, Fig. 6.)}

E. \& E., '90, 11; Eigenmann, Zoe, May, 1890.

This species is found in tide pools nearer low-water mark than Clevelandia. It is not very abundant.

\section{Clevelandia longipinnis (Steindachner). (Plate xIv, Fig. 5.)}

E. \& E., '90, 10; Eıgenmann, Zoe, May, 1890.

This is the most abundant fish in the bay. It is found in great abundance in all the little pools left on mud flats by the receding tide. Like most other species of this family found about San Diego it hides in holes in the mud or sand as soon as disturbed.

\section{Gillichthys mirabilis Cooper. (Plate xv, Fig. 12.)}

Gilbert, Proc. U. S. Nat. Mus. J. \& G., '80, 25; R. Smith, '80; J. \& G., '80a, 455; id., '81, 53; id., '82, 636 ; R. Smith, '85, June; E. \& E., Proc. U. S. Nat. Mus., 1888,463 (as G. townsendi); Zoe, May, 1890.

Very abundant in the sloughs of mud flats. During summer they bite voraciously at all bait offered, especially during the incoming tide. Toward their spawning season they retire to their respective crab holes, and no morsel, be it ever so tempting, will lure them forth. They first spawn at San Diego about the end of March. The young are very active, jumping several times their own length if left dry in a watch crystal. It is the largest of the gobies found about San Diego.

Typhlogobius californiensis Steindachner. (Plates $\mathrm{xV}$ and $\mathrm{xvIII.)}$

Steind. Ichthyol. Beitr., vIII, 23, 1879; R. Smith, Proc. U. S. Nat. Mus., 1881, 19, as Othonops eos; J. \& G., '81, 53; id., '82, 639; R. Smith, '85, June; E. \& E., West. Am. Scientist, June, 1889; Eigenmann, Zoe, May, 1890.

Abundant at Point Loma under rocks between tide marks. The most remarkable of the gobies is undoubtedly the blind one inhab- 
iting the crab holes under rocks at Point Loma. It has been found nowhere else about San Diego, but has been taken at Ensenada. Its habitat is, as far as known, quite limited. In its pink color and general appearance it much resembles the blind fishes inhabiting the caves of southern Indiana. Its peculiarities are doubtless due to its habits. The entire bay region is inhabited by a carideoid crustacean which burrows in the mud. It, like the blind fish, is pink in color. Its holes in the bay are frequented by Clevelandia, etc., while at the base of Point Loma, where the waves sometimes dash with great force, the blind fish is its associate.

On rough days few fish are seen, though ever so many stones are overturned, a task rendered somewhat laborious and bad for the fingers by the numerous worn tubes, etc., attached to the rocks. On mild days, on the contrary, with very low tides, quantities are found, and almost invariably in company with one of the crustaceans mentioned above. Sometimes the fishes live quite out of water on the damp gravel and sand under a rock, but more frequently small pools of water fill all the depressions under the rocks, and the fishes swim rapidly away in their attempt to hide in the crab holes, several of which always branch from the cavity in which the rock has lain.

In the bay the gobies habitually live out of the holes, into which they descend only when they are frightened, while at Point Loma this species never leaves its subterranean abode, and to this fact we must attribute its present condition.

How long these fishes have lived after their present fashion it would be hard to conjecture. The period which would produce such decided structural changes can not be a brief one. The scales have entirely disappeared, the color has been reduced, the spinous dorsal has been greatly reduced; not only have the eyes become stunted, but the whole frontal region of the skull, and the optic nerves have been profoundly ehanged.

The skin, and especially that of the head, has become highly sensitized. The skin of the snout is variously folded and puckered, and well supplied with nerves; the nares are situated at the end of a fleshy protuberance which projects well forward, just over the mouth. At the chin are various short tentacles and a row of papilla, which very probably bear sensory hairs similar to those represented in Figs. 15 and 16 (plate viII), extends along each ramus of the lower jaw, and along the margin of the lower limb of the preopercle. The eye is, however, the part most seriously affected. In the young, Fig. 7, it is quite evident, and is apparently functional. Objects thrust in front of them are always perceived, but the field of vision is quite limited. With age the skin over the eyes thickens, and the eyes are scarcely evident externally. As far as I could determine they do not see at this time, and certainly detect their food chiefly, if not altogether, by the sense of touch. A hungry individual will swim over meats, fish or a mussel, 
etc., intended for its food without perceiving it by sight or smell, but as soon as the food comes in contact with any portion of the skin, especially of the head region, the sluggish movements are instantly transformed, and a stroke of the fins brings the mouth immediately in position for operations.

I have not been able to raise the fishes from the egg. The youngest individual ever seen is represented in Fig. 7.* In this specimen the membranes of the fins were thin, the color cells were well formed and arranged not unlike those of the young Gillichthys, Fig.12. Its movements were similar to those of the other gobies, and not at all sluggish like those of the adult. The favorite position is a standing or sitting one with the broad pectorals extending out at right angles to the body. In this position the fish ean, with a sudden stroke of its pectorals, move quickly and rapidly. In the old the fins are thick and smaller in proportion, and all the vivacity seems to have disappeared. The color has degenerated, or at least not developed in proportion to the growth of the fish.

The minute structure of the eye was not examined. It will be described in another paper. The eye and optic nerve have been isolated by treatment with 20 per cent nitric acid, and by simple dissection of alcoholic specimens. The lens is large in proportion to the size of the eye, which does not materially differ in size in the smallest and largest specimens examined. The optic nerve is very slender and long as compared with that of any of the other gobies.

All the gobies are tenacious of life, especially the blind one. Several of the latter have been kept in a half-gallon jar for several weeks without change of water, and others have been kept several months in confinement in my laboratory. When the water becomes somewhat stale they frequently rise to the surface and use the surface of the water as a plane to which they attach themselves by means of their ventrals.

It was my intention to study the development of the eyes, etc., of this fish, and with this end in view I kept many specimens alive and made frequent trips to Point Loma to procure fresh individuals in order that too long confinement might not have impaired the reproductive function. They spawn in the latter part of May and June, but I have not found the eggs in nature. Those deposited in confinement would not develop, and attempts at artificial fertilization of freshly-caught individuals were not successful. An absence from San Diego prevented

* During the summer of 1891 Mr. L. C. Bragg, of Coronado, found the eggs attached to the lower surfaces of the rocks under which the fish live. He kindly gave me several specimens from which the drawings of plate $\mathrm{A}$, xviii were made. The zona is seen in nature to expand enormously and become club-shaped. In this chamber the young are able to live long beyond the ordinary hatching period of fishes. The eggs are attached to the rocks in a single layer by the network of threads surrounding the micropyle. The eyes develop normally, and those of Fig. 4 differ in no way from the eyes of other fish embryos. This offers a most striking example of degeneration. The minute structure of these larval eyes will be described by one of my students,

Proc. N. M. $92-11$ 
me from visiting their habitat during July, and in August the tides were not favorable.

The earliest date at which I procured young was October 25 ; the smallest eaught at that time is represented in Fig. 7 .

Though I did not secure developing eggs, those procured enable me to describe the remarkable membranes of the egg, which are probably similar in many other gobies.

The covering of the ovarian egg consists first of a finely striate membrane, the zona radiata of all telostean eggs. Exterior to this is a network of threads with the meshes coarsest at the entodermic pole, and forming almost a continuous membrane at the ectodermic pole, Figs. 4 and 5. The eggs were examined from the surface only, and I am not able to say how intimate the connection between the threads and the zona is in the ovary. When the eggs are deposited the meshwork of threads is stripped off the egg and remains attached to the zonaradiata around the micropyle, Figs. 1, 2, 3, and 5. In the eggs deposited naturally by the females in confinement the threads had been wound together to form a cord at the micropylar end of the egg, Fig. 1. The cords of many of these eggs were attached to each other, and the eggs thus came to be laid in bunches like those of grapes. The bunches of eggs resemble so closely those of the crustacean with which this fish is associated, and which spawns at the same time, that the idea of a highly specialized mimicry at once suggests itself. The similarity between the eggs is heightened by the fact that they are both bright yellow. In females with ripe eggs they can frequently be seen forming a yellow band along the flanks.

The yellow of the blind-fish egg is entirely confined to the yolk which contains many oil globules. The granular protoplasm is opaque.

\section{CHIRID Æ.}

Ophiodon elongatus Girard.

E. \& E., Proc. U. S. Nat. Mus., 1888, 465; E. \& E. '89a.

Not very abundant, but probably a permanent resident. It is found in deep water outside the bay only. The young, so abundant in San Francisco Bay, were not seen.

Zaniolepis frenatus E. \& E.

E. \& E. '89a.

One specimen about 160 millimeters long was taken from the stomach of a rock cod on Cortes Banks.

\section{SCORPANIDA.}

We have been able to largely increase the number of species of this family, previously recorded from San Diego, and to make pretty extensive observations on the seasons of maturity of the various species. 
Sebastodes pancispinis (Ayres).

E. \& E. ' 89 .

Moderately abundant throughout the year, reaching a large size. It is one of the more important of the species. With young during December, January, and February.

Sebastodes flavidus Ayres.

J. \& G. '80a, 455; id. '81, 55; id. '82, 657; R. Smith '85, 46; E. \& E. '89.

We have evidently confounded two species under this head. It is not very abundant. With young in January.

\section{Sebastodes serranoides E. \& E.}

E. \& E. '89 (in part as S. flavidus); E. \& E., Proc. Cal. Acad. Sci., Ser. II, Vol. III, $36,1890$.

This species was erroneously recorded by us from Cortes Banks as S. flavidus. It is occasionally brought into the market.

Sebastodes goodei E. \& E.

E. \& E. '90, 12.

This species seems to be abundant in deep water (about 100 fathoms). The largest specimens observed were 550 millimeters. It was taken in January (9 and 29), February (14), and March (4). It is one of the most important of the rock cods in the San Francisco market.

Sebastodes rufus E. \& E.

E. \& E. '90, 13.

This species was observed in November $(14,1889)$ and December (2 and 10, 1889).

\section{Sebastodes ovalis Ayres.}

E. \& E. '89; E. \& E. '89a.

Frequently brought to the market, but not in large numbers. It was taken on Cortes Banks. Among many specimens brought into the market October 15 two were gravid. The eggs in both were in nearly the same stage of development. Some of the embryos were still alive, the heart beating. The eggs are more spherical than in rubrovinctus of the same stage and there is as yet no pigment formed anywhere. There is usually but a single large oil sphere, but not rarely there are two or three.

\section{Sebastodes mystinus Jordan \& Gilbert.}

J. \& G. '80a, 455; id. '81, 56; id. '82, 659; R. Smith, '85, June; E. \& H. '89 (as S. melanops); E. \& E. '89a.

Abundant on Cortes Banks and not infrequently brought into the market. 
Sebastodes proriger Jordan \& Gilbert.

E. $\&$ E. ' 90,15 .

Not very abundant, but much larger in size than farther north. Jordan \& Gilbert state that it reaches a length of 250 millimeters. The largest observed by us measured 600 millimeters.

\section{Sebastodes atrovirens Jordan \& Gilbert.}

J. \& G. '80, 27; R. Smith' 80 ; J. \& G. '80a, 455; id. ' 81,56 ; id. '82, 661; R. Smith '85, June.

Only a single specimen noticed (August 23).

Sebastodes melanostomus E. \& E.

E. \& E. '90, 17.

A single specimen, about 55 millimeters long, taken November 14, 1889.

\section{Sebastodes pinniger (Gill).}

E. \& E. '90, 16.

Much less abundant than farther north. It is found in deep water (100 fathoms). It was brought to the market on the following dates: December 3, 5, and 11; January 13 and 21; February 14; March 1.

Sebastodes miniatus Jordan \& Gilbert.

R. Smith, '85, June; E. \& E., '89.

This is the most abundant and by far the most important of the Rock Cods. It surpasses in abundance all the rest combined and large numbers are daily brought into the market. The half-grown, those about 10 inches long, abound in the kelp in November. These have black. margined fins. The old ones live in deeper water.

They are with young in December and January and during that time the bottoms of the Rock Cod boats are covered with the eggs and young pressed out by the superimposed fish.

It is abundant on Cortes Banks.

Sebastodes ruber (Ayres). (Plate xvi, figs. 4-7.)

E. \& E., '89; E. \& E.. '89a.

Not abundant, but frequently brought to market.

With young on Cortes Banks in July and August. The oil globule is small and the larva quite long at the time of hatching. There is a series of pigment spots along the lower part of the tail and over the abdomen.

\section{Sebastodes rosaceus (Girard).}

Girard, Pacific R. R. Survey x. 78, 1859. E. \& E., '89; E. \& E., '89a.

Quite abundant, but usually either used for bait or thrown overboard on account of its small size. For the same reason that it is least prized in San Diego it is most preferred in San Francisco, where small Rock Cod always have a readier market than large. 
Sebastodes constellatus Jordan \& Gilbert.

R. Smith, '85, June; E. \& E., '89.

Abundant, reaching a larger size than rosaceus. The ovaries of some were empty on November 12.

E. \& E., '90, 20.

Sebastodes æreus E. \& E.

Rare. This species was observed on November 7 and January 9 aL . 24. Type U. S. Nat. Mus., No. (41868.)

Sebastodes chlorostictus Jordan \& Gilbert.

E. \& E., Proc. U. S. Nat. Mus., 1888, 465; E. \& E., '89.

Abundant. In the markets almost daily with S.miniatus. This species is with young in February or March. Abundant on Cortes Banks.

E. \& E., '90, 18.

Sebastodes eos E. \& E.

Very similar to chlorostictus, but less abundant. It was observed November 14, December 4 and 10, abundant on the latter date, and on February 21.

\section{Sebastodes gilli R. Eigenmann.}

R. S. E., Am. Nat.

Three specimens of this species were taken within a few days of each other about the middle of November, 1890. The types of these species are in the British Museum.

Sebastodes elongatus Jordan \& Gilbert.

E. \& E., '89; E. \& E., '89a.

Quite abundant, but, with rosaceus usually discarded. It is usually present in all catches of Rock Cod made in shallow (50 fathoms or less) water. At San Francisco it has a ready market.

Sebastodes levis E. \& E.

E. \& E., '89; E. \& E., '89a.

This is the largest of the Rock Cod, reaching a weight of 29 pounds. it is almost daily brought into the market. Seventeen individuals is the largest eatch reported by a single boat in a day. It is common on Cortes Banks. Types U. S. Nat. Mus., No. (41904.)

With young in January and February.

This species is so closely related to $S$. rubrovinctus that at one time I supposed the two species identical. I have been able to compare specimens of the two species of the same size (about $490 \mathrm{~mm}$. long) with the following results:

a. Eye very large, orbit $\frac{3}{4}$ in snout, $3 \frac{1}{2}$ in head; interorbital equal to snout, concave; preocular spines short, bulging outward; supraocular short, heavy, blunt; the two upper preopercular spines directed backward, the three lower downward; preorpital spines sharp, the posterior tricuspid; gill rakers long, nearly equal to maxillary width, $9+21$; membranes of first five dorsal spines meeting the succeeding spine below its middle. Head broad and short, its width between upper angle of preopercle $2 \frac{1}{3}$ in its length, $2 \frac{6}{7}$ in the length, depth about equal to the length of the head; bases and anterior portion of spinous dorsal membranes scaled; peritoneum gray. Axil red ................... rubrovinctus. 
aa. Eye small, orbit $1 \frac{1}{2}$ in snout, $4 \frac{8}{4}$ in head ; interorbital $1 \frac{2}{3}$ in snout, convex or flattish; preopercular spine slender; supraocular slender, sometimes continued to the postocular without spine; the four upper preopercular spines directed backward, the lowest one downward; preorpital crenulate, without spines; gill rakers short, less than one-third of maxillary width, $8+21$; membranes of first seven dorsal spines meeting the succeeding spine below the middle; the membranes much more deeply incised than in rubrovinctus. Head compressed, its width between upper angles of preopercles $2 \frac{1}{2}$ to 3 in its length, which is about $2 \frac{4}{7}$ in the length; depth; membranes of spinous dorsal naked; peritoneum white.

Pink; axil and region above it dusky; four indistinct dusky vertical bars less than half as wide as eye; one below first dorsal spine, one below the sixth, one between tenth and eleventh, and one below middle of soft dorsal; a few indistinct dark spots on upper part of opercular membrane ................. levis

\section{Sebastodes rubrovinctus Jordan \& Gilbert.}

E. \& E., '89; E. \& E., '89a.

Most nearly related to S. levis. Not frequently brought into the market and never more than two seen on any one day. It is one of the rarer species and has not. previous to this year, been recorded from San Diego. It has proved an excellent object for determining the probable duration of gestation. From the individuals brought to my notice it would seem that the eggs are ripe in all individuals at nearly the same time. One individual of September 14 had ripe eggs which were free or only mechanically inclosed in the follicle. On September 16 the first developing eggs were observed, the gastrula covering about onethird of the yolk. No more individuals were seen till October 9, when there were two females, one of which had given birth to all its young, in the other the embryos were nearly ready to hatch. On October 11 another female was observed with young of about the same size as those of October 9 . The time required to hatch eggs of rubrovinctus is, therefore, not far from a month.

The ripe egg is spherical, about 0.9 millimeter in diameter, with one large and several smaller bright, greenish-yellow oil globules the largest measuring 0.32 millimeter in diameter. It is surrounded by a thin membrane. As the embryo nears hatching its tail is brought forward below and curled over the head. The ovum thus assumes a compressed ovate shape, the two larger diameters measuring 1 and 1.3 millimeters, respectively. The eyes are slightly pigmented and there are a few minute pigment cells along the posterior intestinal tract. The tail is entirely free from pigment. The oil globules have united into one, which lies near the middle of the lower surface of the yolk. It was noticed that those eggs most nearly associated with the follicles were slightly further along in their development.

The larvæ are retained some time after hatching. An individual of October 28 contained larvæ 5 millimeters long. The striking feature at this stage is the prolonged lower jaw, which resembles that of the adult Sebastodes paucispinis Ayres. A series of black pigment spots along the lower edge of the tail; a few pigment spots on dorsal surface of 
head. Sides of abdomen more densely pigmented; pectorals with many black pigment cells.

The ovaries are two large sacs, from the dorsal walls of which the oviferous tissues are suspended. Shortly after giving birth to its young the oviducts shrink and the ovaries occupy but a small space. It was stated above that the eggs are freed from the follicle before they are fertilized. It must be borne in mind, however, that this species lives at a considerable depth of water and that many of the tissues are distorted when the fish is brought to the surface and the great pressure of water is removed. To this cause is perhaps to be ascribed the fact that the eggs readily flow from the body with slight pressure at any time during gestation.

Sebastodes auriculatus (Girard). (Plate xvi, tigs. 1-3.)

R. Smith, '85, June.

This species is common in shoal water with the young of S. miniatus. It does not enter the bay as it does at San Francisco, and little use is made of it, on acceunt of its small size. It is a valuable fish and will doubtless be utilized in the near future. The egg possesses a very large yellow oil sphere and the larvæ are not pigmented at hatching.

Sebastodes rastrelliger Jordan \& Gilbert.

Only a single individual observed, on August 23.

Sebastodes vexillaris Jordan \& Gilbert.

J. \& G., '80a, 455; id., '81, 58; id., '82, 672; R. Smith, '85, June; E. \& E., Proc. U. S. Nat. Mus., 1888, 465 ; E. \& E., '89 (as S. carnatus).

Next to S. miniatus this is probably the most abundant of the Rock Cods. It is highly prized, being considered especially fine flavored and fat. It is hardier than the other species and is frequently brought into the market alive. While all the other species caught on Cortes Banks ejected the stomach when brought to the surface, this species retained it. It equals $S$. miniatus in size and its infinite variations from bright scarlet to flesh color and dark olive render it sometimes difficult of determination. We soon found that if there was anything "curious" in the markets which in any way resembled this species it was pretty safe to call it vexillaris.

It is with young in February; the embryos are sometimes still alive when brought to market.

Sebastodes chrysomelas Jordan \& Gilbert.

R. Smith, '85, June; E. \& E., '89 (as S. chrysomelas purpureus).

Abundant in shallow water and usually discarded on account of its small size. It varies greatly in color and the variety named by us is scarcely worthy of a name. It does not frequently come into the markets, since the regular rock-cod boats usually go beyond its haunts to fish in deeper water. 
R. Smith, '85, June.

s. carnatus Jordan \& Gilbert.

Sebastodes serriceps Jordan \& Gilbert.

J. \& G., '80a, 455; id., '81, 59; id., '82, 676; R. Smith, '85, June; E. \& E. '89. Common, but not frequently brought to market.

Scorpæna guttata Girard. Sculpin.

J. \& G., '80, 27; R. Smith, '80; J. \& G., '80a, 455; id., '81, 59; id., '82, 679; R. Smith, '85, June; E. \& E., '89.

Very abundant both in and outside the bay. It is not frequently brought from beyond Ballast Point, and is only occasionally taken in seines. It abounds especially about the piles of the various wharves and is caught with hook and line. The various spines about the head, which are said to be poisonous, do not make it a desirable fish to handle and its general appearance precludes it from coming into favor generally. It is said to be one of the best fishes of the bay.

Those caught in the bay are usually of a dull color, while those from outside are bright scarlet intermixed with other brilliant colors.

It was taken on Cortes Banks.

COTTIDÆ.

Leptocottus armatus Girard.

Girard, Pacific R. R. Survey, x, 60, 1859; J. \& G., '80, 25; R. Smith, '80; J. \& G., '80a, 455; id., '81, 60; id., '82, 713; R. Smith, '85, June.

Common in the bay. Of no economic importance.

Leiocottus hirundo Girard.

E. \& E., '90, 21.

Only a single ind ividual seen from the bay. Taken January 31, 1890.

Oligocottus analis Girard. (Plate xvii, Figs. 1-15.)

J. \& G., '80, 25; R. Smith, '80; J. \& G., '80a, 455; id., '81, 59; id., '82, 717; R. Smith, '85, June; E. \& E., West. Am. Scientist, June, 1889.

Very abundant in all rocky ocean tide pools; never seen in the bay.

The spawning period probably extends over considerable time. Small specimens procured in the latter part of January have apparently ripe eggs. Of a large number of individuals collected on March 27, a single one was with ripe eggs, and the presence in tide pools of minute but fully developed individuals would indicate that the time of spawning extends back two or three months.

The eggs of the individual eaught March 27 were artificially fertilized at 8 p. m. of that date. The eggs measure 1.2 millimeters in diameter, are of a brownish-yellow color, and have one large and from five to vine smaller oil globules. The larger globule measures about $150 \mu$. 
They are surrounded by a thick zona which appears to be perforated by two sets of canals, the usual fine canals and fewer much larger canals. In optical section these coarser canals appear as dark lines. The eggs readily adhere to each other, though they do not seem to possess the power of fastening themselves to foreign objects. When once fixed to each other they can scarcely be separated without injuring the zona.

Ten hours after fertilization, eggs with one, two, four, and eight cells, respectively, were observed (Figs. 1-7). Thirteen hours after fertilization the most advanced eggs showed the sixteen-cell stage. The cells in this stage do not seem to be definitely arranged as in the eight-cell stage. Sixteen hours after fertilization the two layers of cells have been formed (Fig. 8).

The blastoderm is completely segmented in thirty-five hours. At this time free nuclei are abundant. Stages immediately following are somewhat obscured by the opacity of the yolk. A well-advanced stage is represented by Fig. 9. The oil globules do not seem to have any definite relation to the blastoderm though they assume a more definite relation as soon as the embryo is outlined. At this stage they lie opposite the middle of the embryo; as the embryo grows over the yolk they come to lie just in front of the snout. By the further reduction of the yolk the oil globules finally lie beneath and slightly behind the auditory capsule. The posterior end of the embryos figured (in Figs. 9 and 10) terminates in a mass of large cells or rather small vesicles, the larger of which is situated below and may represent Kupffer's vesicle, while after sixty hours the gastrula covers half the yolk, the blastopore is closed in some of the eggs after eighty-six hours.

In the stage represented in Fig. 9 the yolk is covered by a network of fine lines which converge toward the tail of the embryo.

On the fifth day the auditory capsule and the heart make their appearance (Fig. 10). The heart lies somewhat to the left of the middle of the body. The body of the embryo at this time surrounds about half the yolk and the tail extends free one-third farther. The tail now lengthens rapidly, the pectoral fins being formed at the same time.

The circulatory system is next outlined; it is from the beginning decidedly sinistral. The liver is at this time represented by a vascular network overlying the yolk to the left of the embryo. The many vessels coming from the liver are collected in a large vein which at first is entirely on the left half of the yolk; at the time of hatching, however, it has been carried to the right side; with the reduction of the yolk this vein is greatly shortened in proportion to the veins emptying into it.

The pigmented regions are outlined by the eleventh day. They are at this time distributed as they are when the yolk is almost absorbed. Round orange dots are also present at this time along the pigmented area.

Peculiar granular cells or patches are formed about the head by the fourteenth day. These patches persist until the embryo is hatched 
when they disappear within a very short time. Similar patehes were seen in the smelt.

The first embryo hatched on the eighteenth day, the last on the 24th day. They measure from 3.7 to 4.2 millimeters.

The eyes at the time of hatching are well pigmented; in some of the embryos there is a pigment cell above the left eye, in some a cell over each eye, but in the latter case the one over the left eye is always the larger. A group of pigment spots lies on the nape, the upper two being somewhat removed from the rest. There is a broad black disk of pigment cells overlying the body cavity. Seen from the side it appears as a curved black bar; as seen from above it is shield-shaped. The individual cells forming this disk are contractile and the disk as a whole can be contracted to less than one half its normal size. This is usually done just before the larva moves. About thirty-four pigment cells lie along the base of the anal fin fold. Shortly after hatching the pigment cells near the tip of the tail send out pseudopods into the fin fold and a few days after hatching several pigment cells are seen in the fin fold at this point. A series of round orange cells margin the dark disk and are variously distributed over the head. These cells can be enormously expanded, giving the fish a bright yellow appearance.

At this time the mouth opens frequently, the intestines are well developed, and seem to contain foreign substance. The branchial filaments are just beginning to bud.

The oil globules, two in number, are fixed on the right side in the yolk just behind the head. The liver covers the upper left half of the yolk. As the yolk is reduced and the posterior intestines are more developed the liver is crowded forward and the green bile sack can be seen near its posterior border (Fig. 15).

The dorsal aorta is bent down near the tip of the tail and the larger vein is returned above to the place where the aorta is bent down, where it crosses it and returns to its normal position.

The median fin fold is continuous from the nape to the vent and did not undergo any marked changes before the yolk was absorbed except the formation of primitive rays in the tail.

There are no marked changes in the embryo from the time of hatching to the time the yolk is absorbed. Beyond that stage it was impossible to keep the young.

Icelinus australis E. \& E.

E. \& E., '89.

Known from two specmens taken from the mouth of a Sebastodes on Cortes Banks.

Paricelinus hopliticus E. \& E.

E. \& E., '89.

Known from a single specimen taken from the mouth of a Sebastodes on Cortes Banks. 
Scorpænichthys marmoratus (Ayres).

J. \& G., ' 80,27 ; R. Smith, ' 80 ; J. \&. G., '80a, 454; id., '81, 60; R. Smith, '85, June.

Probably common near the kelp. It is seldom brought into the market and does not have a ready sale on account of its slimy appearance and its sometimes green tint.

\section{AGONID $\mathrm{E}$.}

\section{Brachyopsis species?}

E. \& E., '89.

Fragments of a species of this genus were obtained from the stomachs of rock-cod on Cortes Banks.

\section{GOBIESOCID $\mathrm{E}$.}

Gobiesox rhessodon R. Smith.

R. Smith, Proc. U. S. Nat. Mus., 1881, 140; J. \& G., '81, 63; id., '82, 749; R. Smith, '85, June.

Common under rocks and among ulva and zostera on ocean beaches.

Gobiesox eigenmanni Gilbert.

Gilbert, Proc. U. S. Nat. Mus., XIII, 1890.

One specimen from among zostera at Point Loma.

\section{BATRACHID王.}

\section{Porichthys margaritatus Richardson.}

Girard, Pacifie R. R. Survey, x, 134, 1859; J. \& G., '80, 27; R. Smith, '80; J. \& G., '80a, 454; id., '81, 65; id., '82, 751; R. Smith, '85, June; E. \& E., West Am. Scientist, May, 1889; E. \& E., '89.

Very common everywhere, forming an important item in the food of rock-cod on Cortes Banks.

\section{BLENNIIDA.}

Isesthes gentilis Girard.

Steind. Ichthyol. Beitr. 149, 1876; J. \& G., '82, 959; R. Smith, '85, June.

Very abundant in the bay in April and May. Ripe males and females were abundant May 29. They sometimes inhabit tin cans near low-tide mark. Their presence can be detected by the fact that the ean and the space surrounding it are kept free from all visible organisms.

\section{Isesthes gilberti Jordan. (Plate xvii, Figs. 16-20.)}

J. \& G., '80, 25 (as H. gentilis); R. Smith, '80; J. \& G., '80a, 454; id.' '81, 63; id., 82, 757; R. Smith, '85, June; E. \& E., West Am. Scientist, June, 1889.

This species is found associated with Oligocottus analis, Clinus evides, Auchenopterus integripinnis and Heterostichus rostratus in the rocky tide pools of the ocean beaches. 
Ripe females were found March 27. The majority of the females were not ripe and the spawning time may be placed as April.

The eggs are quite remarkable in their structure and coloration. To the unaided eye they appear opaque, of a purplish pink color inside of which is a spot of brownish red and upon it a dot of opaque white.

The greater portion of the egg is covered by a thin transparent membrane but at one portion there is a large opaque cushion by which the egg fastens itself to foreign bodies. When fastened the egg becomes depressed. The longer axis measures $825 \mu$, the shorter $562 \mu$. The diameter of the cushiony cap is $975 \mu$. This cap on sections of the ovary and of the ripe eggs is seen to be composed of innumerable very fine filaments, the tips of which are swollen and club-shaped. Their small size, the great number and their aggregation at one pole of the egg render their filaments different from all the other appendages of fish eggs yet described.

The yolk is composed of rather large spheres. On its upper surface are imbedded several pale yellow oil globules and about an equal number of bright purple oil globules (black in Fig. 16, pl. x.) In the middle of these is a larger white body the function of which is not known. Younger ovarian eggs 0.625 millimeters in diameter are entirely composed of purple spheres while still younger ones are colorless.

The germinal disk is always formed beneath the cap of filaments regardless of the position of the cap whether at the side, above, or below. This fact renders the early stages in the development obscure. The germinal disk is seen in Fig. 16. The first segmentation is completed in about ten hours after fertilization and results in two elongate cells whose longer axes lie parallel, Fig. 17. After fifteen and a half hours eight cells were observed. In this egg in which the cap was placed above, the oil globules and white disk appeared to lie below the germinal cells, a fact which would indicate that the oil globules were mobile in the yolk and tended to lie at the top. The oil globules therefore have, in this case, no influence on the position of the germ. Further stages in the segmentation of the germinal disk could not be observed.

The next stage which could be satisfactorily observed was one hundred and thirty-two hours old. It is represented in Fig. 19. The eyes at this time are well along in their development. The embryo embraces about half of the yolk and seems to be composed of large cells perfectly transparent. The purple oil globules (not figured) occupy the center of the field while the white body lies directly beneath the tail. Several black pigment cells have been found and lie on the yolk. The yellow oil globules still remain arranged about the white body.

On the seventh day the heart beats slowly. The pigment spots on the surface of the egg have greatly increased in number. It was now observed that the position of the embryos at this stage are independent of the opaque cap. 
Clinus evides Jordan \& Gilbert.

Steind. Beitr. v, 149, 1876 (as Blakea elegans); J. \& G., '80, 27 (as Gibbonsia elegans); R. Smith, '80 ; J. \& G., '80a, 454; id., '81, 63; id., '82, 763; R. Smith, '85, June.

Abundant on rocky ocean beaches and tide pools; never brought to market.

Heterostichus rostratus Girard. Kelpfish; Bandfish.

Girard, Pacific R. R. Survey X, 37, 1859; J. \& G., '80, 25; R. Smith, '80; J. \& G., '80a, 454; id., 81, 63; id., '82, 764; R. Smith, '85, June.

Common both in the bay and outside. It is rarely brought into the market, and is of no economic importance.

Auchenopterus integripinnis R. Smith.

R. Smith, Proc. U. S. Nat. Mus., III, 147, 1883; R. Smith, '80; J. \& G., '80a, 454; id., '81, 63; id., '82, 764; R. Smith, '85, June.

Rare; in tide pools near La Jolla.

Neoclinus blanchardi Girard.

Girard, Pacific R. R. Survey X, 114, 1859.

Not seen by us.

\section{FIERASFERIDA}

Fierasfer dubius Putnam. (Pl. xvi, Figs. 8-10.)

E. \& E., '89a.

Some eggs were collected which probably belong to this species.

These eggs were incidentally procured with a dip net on Cortes Banks while fishing for other things. They are imbedded in a perfectly transparent jelly of the consistency of white of egg. The nature of the mass of eggs thus dipped up was not understood, as the eggs are quite as transparent as their matrix. There were through the whole mass sets of two black dots and a black streak, and on placing a portion in Perenyi's fluid the contour of the eggs was immediately made evident. The whole mass measured about half a pint. The eggs measured 0.8 millimeters and are arranged in one layer and separated from each other by a small space. Some of the eggs had hatched, and one of these larvæ is shown in Fig.1. The pectorals are well developed. The eyes are black and the intestinal canal as far as developed is covered with dendritic pigment cells, a few of which extend on the yolk sack. Otherwise no pigment is developed.

\section{OPHIDIID A.}

E. \& E., ' 88 .

Otophidium taylori (Girard).

This species is occasionally taken in the bay. It was abundant among the spewing of the rock-cod taken on Cortes Banks. 


\section{GADID压.}

E. \& E., '90, 21.

\section{Merlucius productus (Ayres).}

Only three specimens of this species have been observed. The first was taken November 6 , the other two January 9.

\section{PLEURONECTIDÆ.}

\section{Citharichthys sordidus (Girard).}

J. \& G., '80, 23 ; R. Smith, '80; J. \& G., '80a, 453; id., '81, 67; id., '82, 817 ; R. Smith, '85, June; E. \& E., '89 (as P. californicus).

In deep water with Rock Cod. The first of the season were independently brought by several boats on October 7,1889 . It became quite abundant by the end of the month, but was never taken in quantity. It was seen as late as February 24. Whether it is not also found later, as is probable, I am unable to say. It has a ready market, but as only a few are caught it is of no great economic importance.

\section{E. \& E., '90, 23.}

Eopsetta jordani (Lockington).

Only a single specimen has so far been recorded from San Diego waters. It was taken in about 100 fathoms outside the bay.

Paralichthys californicus (Ayres).

Girard, Pacific R. R. Survey, x, 147, 1859 (as P. maculosus); J. \& G., '80, 27 ; R. Smith, '80; J. \& G., '80a, 454; id., '81, 66; id., '82, 821; R. Smith, '85, June.

The young of this species are abundant in San Diego Bay throughout the year. The adult, or rather half grown, enter the bay in February. The species is taken with hook and line off wharves and in seines. Those caught in seines are mostly too small for capture. Near San Pedro large quantities of this species are taken with trawls about 5 miles off shore, in shallow water ( 5 fathoms) with sandy bottom. Similar methods have not been attempted at San Diego.

E. \& E., '90, 22.

Hippoglossina stomata E. \& E.

Known from two specimens taken in deep water November 7, 1889. The eggs measure 1.2 millimeters in diameter; the singleoil globule, 0.16.

E. \& E., ' $89 a$.

Xystreurys liolepis J. \& G.

This species entered the bay during October and November. It was never in great abundance.

\section{Pleuronichthys coenosus Girard.}

R. Smith, '80; J. \& G., '80a, 453; id.,' 81 , 68; id., '82, 830; R. Smith, '85, June.

Abundant with the next. It is taken with seines in the bay. We found it with ripe eggs the latter part of April, and Mrs. Eigenmann procured it with ripe spawn August 22, 1882. 
Hyspopsetta guttulata (Girard).

J. \& G., '80, 27 ; R. Smith, '80; J. \& G., '80a, 453; id., '81, 68; id., '82, 830 ; R. Smith, '85, June.

This species enters the bay in large numbers during February and March. Many are then eaught with seines and with hand lines. Though the bulk of those entering the bay may not remain it is always more or less abundant.

Ripe individuals of both sexes were abundant in April and the eggs were procured with surface nets.

As stated under the head of Scicna saturna, the eggs and larvæ of these two species resemble one another greatly. The color cells in this species do not appear till the gastrula covers two-thirds of the yolk, and on hatching there are a few more color cells on the tail than in Scicena.

\section{Symphurus atricauda Jordan and Gilbert.}

J. \& G., '80, 23; R. Smith, '80; J. \& G., '80a, 453; id., '81, 69; id., '82, 842; R. Smith, '85, June.

Only one specimen of this species was brought to market (November 5). It is said to be abundant on muddy bottoms somewhat deeper than that reached by the ordinary seines.

\section{TETRAODONTIDA.}

\section{Sphæroides politus (Girard.)}

Girard, Pacific R. R. survey, x, 340, 1859; R. Smith, '80; J. \& G., '80a, 453; id., '81, 70; id., '82, 860; R. Smith, '85, June.

Not seen by us.

\section{DIODONTIDA.}

Diodon hystrix L.

J. \& G. '80a, 453; id. '81, 70.

Chilomycterus californiensis Eigenmann.

Am. Nat., 1891. Proc. U. S. Nat. Mus., 1892.

One specimen of this species was discovered at San Pedro.

\section{MOLIDA.}

\section{Mola mola (Linnæus.)}

R. Smith, '80; J. \& G., '82, 866; R. Smith, '85, June.

This species is occasionally gaffed off Point Loma and stray individuals are at times drifted into the bay. It is probably migratory.

\section{EXPLANATION OF PLATES.}

The numbers and letters refer to ziess objectives and oculars. All the sketches were made with an Abbe camera unless otherwise stated. 


\section{Plate X.}

Figs. 1-5. Stoiephorus compressus,

Fig. 1. First egg found April 24. A \& 4.

2. Ovum procured April 26 and hatched in 60 hours. A \& 4 .

3. The same 10 hours after, Fig. 2 . A \& 4 .

4. Another, older embryo. A \& 4 .

5. A larva some time after hatching. A \& 4 .

Figs. 6-9. Species No. 1.

Fig. 6. An undetermined egg, found Au- Fig. 8. Another egg found August 28. gust 14 . A \& 4 .

7. The same four hours later. A \& 4 .

A \& 2 .

Figs. 10-13. Species No. 2.

Fig. 10. An egg procured April 26. | Figs. 11-13. Later stages of the same.

Plate XI. Clupea mirabilis.

These figures were made with a coverslip camera and a Bausch \& Lomb 1-inch objective and B ocular.

Figs. 1-4. Forming blastodisk about one Figs. 20. After eight hours and a half. hour after fertilization.

5-14. The ingrowth and receding of the first cleavage furrow.

15. Beginning of second furrow.

16, 17. At completion of second segmentation.

18. At completion of third segmentation.

19. After 4 hours and a half.

21. After twelve hours.

22, 23. After twenty-three hours.

24. After thirty-six hours.

25. After forty-five hours.

26. After forty-nine hours.

27. After fifty-four hours.

28. After fifty-five hours.

29. After seventy-eight hours.

Plate XII. Stolephorus ringens and delicatissimus.

All figures drawn with an Abbe camera and A. and 2 of Zeiss.

Fig. 1. The blastoderm well segmented, bridging over the depression in the yolk forming the segmentation cavity. Optical section. The periblast lining the base of the cavity. Probably thirteen hours old.

2. Gastrula covering about half the yolk, the anterior and posterior lips equally advanced. Showing the segments of the yolk, which, for convenience, are omitted from the other figures.

3. About eighteen hours old.

4. Between nineteen and twenty hours old, showing that the blastopore closes at or very near the entodermic pole of the egg. $12: 30$ p. m., April 18.

5 -10. Illustrate the different stages between Fig. 4 and the time of hatching. 5 sketched at $2: 30$ p. m. ; 6 at $2: 59$ p. m. ; 7 at $3: 40 ; 8$ at $4: 45 ; 9$ at $8: 30 ; 10$ at 4 p. m., April 19.

11. Sometime after hatching; $1: 30$ p. m., April 20; 1.47 millimeters long.

12. Sketched at 8 a. m., April 21, 1.79 millimeters long.

13. Sketched at 4 p. m., April 21, 2.12 millimeters long.

14. The oldest larva seen (forty-eight hours after hatching).

Plate XIII. Atherinopsis californiensis.

All the figures are made from living eggs. Figs. 2-12 Abbe camera, D and 2; Figs. 1 and 13-23 Bausch and Lomb 1 inch and B, coverslip camera.

Fig. 1. Base of one of the filaments of the zona. The zona somewhat shriveled, the yolk having been removed.

2-9. A series of sketches showing one of the waves of contraction approaching the ectodermic pole, and the stage (Fig. 9) just preceding another of these waves. 
Fig. 10. A late stage in the formation of the blastodisk.

11. Preparing to segment.

12. An early stage in the first segmentation.

13. Optical section at the completion of the first segmentation.

14. Surface view of the four blastomeres.

15. Surface view of the third segmentation furrows.

16. Optical section of sixteen cells.

17. Optical section after fourteen hours.

18. Optical section after twenty-four hours.

19. Optical section after thirty-two hours.

20. Diagram of embryo after sixty-four hours.

21. Diagram of embryo after seventy-five hours.

22. Embryo of six and a half days.

23. Embryo in later stage showing yolk circulation.

24. This is probably an Atherinops having been procured as late as April 22 . It measured $5 \frac{1}{2}$ millimeters.

25. An Atherinopsis 9 millimeters long.

26. An Atherinopsis 12 millimeters long.

27. An Atherinopsis 14 millimeters long.

\section{Plate XIV.}

Fig. 1. (Destroyed). Young Clevelandia or Lepidogobius taken with a surface net.

2. An older lava of the same.

3. Tail of a larvæ intermediate between Figs. 1 and 2 .

4. Tail of an older larva.

5, 5a. Clevelandia longipinnis.

6,6a. Gillichthys y-cauda.

\section{Plate XV.}

Fig. 1. Egg of Typhlogobius californiensis undergoing the first eleavage.

2. Micropylar region of an egg of the same species under pressure, showing the margin of the attachment of the outer membrane.

3. An egg forced from the ovary. A very large breathing chamber has been formed. Abnormal (?).

4. A portion of the network of the outer membrane remote from the micropyle of the egg represented in Fig. 3.

5. Micropylar region of the egg represented in Fig. 3.

6. Adult Typhlogobius, natural size, in the position usually assumed in the aquarium.

7. Young Typhlogobius. $\times 4 \frac{2}{9}$, showing color markings and the eye.

8. Dorsal view of skull of Typhlogobius. $\times \frac{2}{3}$.

9. Lateral view of same. $\times \frac{2}{3}$.

10. Ventral view of same. $\times 1 \frac{1}{8}$.

11. Eye, optic nerves and portion of brain of same, showing the very much elongate slender optic nerves and the comparatively large lens as compared with the cup of the eye. $\times 24$, from nitric acid maceration of a specimen $13 \mathrm{~mm}$. long, January 29, 1888.

12. Gillichthys mirabilis. 21 millimeters long.

13. A single scale of same more enlarged.

14. Several scales with color cells from the tail of same.

15. Sense organs of the lateral line of a younger specimen of Gillichthys, from about the middle of the body.

16. Solitary sense organ of the same from the base of the caudal.

Proc. N. M. 92 12 


\section{Plate XVi.}

All the figures were drawn with an Abbe camera from dead or preserved specimens.

Figs. 1-3. Sebastodes auriculatus.

Fig. 1. An embryo some time before hatching, showing the large yellow oil sphere.

2. A larva shortly before hatching.

3. A larva just hatched.

Figs. 4-7. Sebastodes ruber.

Fig. 4. A larva shortly after hatching.

5-7. A larva shortly before hatching in different positions from the same ovary as Fig. 4.

Figs. 8-10. Fierasfer dubius.

8. A larva just hatched and still inclosed in the viscid mass; the vesicle surrounding the head may be an artificial condition caused by imperfect preservation.

9-10. An embryo in two different positions.

11. An embryo of October 15 .

Fig. 11. Sebastodes ovalis.

\section{Plate XVII.}

Figs. 1-15. Oligocottus analis.

Fig. 1. The germinal disk ten hours after fertilization. $\times 50$. Probably an unsegmenting egg, since the germ is well constricted off from the yolk.

2. The same, seen from above.

3 . The two cells of another egg at the same time. $\times 50$.

4. The egg represented in Fig. 3 seen in profile. $\times 50$.

5. The four cells of another egg at the same time. $\times 50$.

6. Another egg with eight cells after ten hours. $\times 50$.

7. The same egg seen in profile.

8. The beginning of two-cell layers after sixteen hours $\times 50$.

9. An embryo after eighty-four hours. $\times 50$; showing how the zona-radiata is appressed by contact with another egg.

10. An embryo after five days.

11. An embryo eight days old.

12. Front view of an embryo seventeen days old.

13. Dorsal view of an embryo on the eighteenth day.

14. Dorsal view of a larva twelve hours after hatching.

15. A larva two days after hatching.

Figs. 16-20. Isesthes gilberti.

16. An egg shortly after extrusion, the shaded portion representing the salmoncolored yolk "y"; the black bodies represent the purple oil-spheres; the white bodies the yellow oil-spheres and the central shaded circle the opaque white globule. The germinal disk "g" is almost completely hidden by the cushion of filaments " $f$."

17. Two cells.

18. Eight cells seen through the cushion.

19. A larva one hundred and thirty-two hours old, the outline of a few of the yolk spheres in the center.

20. An embryo of the eighth day showing the circulation of the left side.

\section{Plate XVIII.}

Fig. 1. The youngest Typhlogobius seen. Zeiss A and 2.

2. The head of an older one from the side.

3. The head of one similar to Fig. 3. seen from below.

4. Another larva forty-eight hours older than Fig. 1. The oldest one seen. It is still inclosed in its club-shaped zona. 


\section{$2 \mathrm{BHL}$ Biodiversity Heritage Library}

Eigenmann, Carl H. 1892. "The fishes of San Diego, California." Proceedings of the United States National Museum 15(897), 123-178.

https://doi.org/10.5479/si.00963801.15-897.123.

View This Item Online: $\underline{\text { https://www.biodiversitylibrary.org/item/53607 }}$

DOI: https://doi.org/10.5479/si.00963801.15-897.123

Permalink: https://www.biodiversitylibrary.org/partpdf/52687.

\section{Holding Institution}

Smithsonian Libraries

\section{Sponsored by}

Smithsonian

\section{Copyright \& Reuse}

Copyright Status: Public domain. The BHL considers that this work is no longer under copyright protection.

This document was created from content at the Biodiversity Heritage Library, the world's largest open access digital library for biodiversity literature and archives. Visit BHL at https://www.biodiversitylibrary.org. 